\title{
DOPUSTNOST FINANČNE ASISTENCE ODVISNE DRUŽBE ZA OBVEZNOSTI OBVLADUJOČE DRUŽBE
}

Prof. dr. sc. Saša Prelič*

Prof. dr. sc. Marijan Kocbek**

\author{
UDK: 347.724 \\ https://doi.org/10.30925/zpfsr.39.4.4 \\ Ur.: 4. rujna 2018. \\ Pr.: 14. listopada 2018. \\ Izvorni znanstveni rad
}

\section{Povzetek}

Avtorja v prispevku obravnavata dopustnost različnih oblik finančne asistence med družbo in njenimi družbeniki oziroma delničarji. Predstavljena je ureditev $v$ slovenskem pravu družb, vključno z aktualno slovensko in nemško sodno prakso. Njuna temeljna ugotovitev je, da je posojila družbe družbenikom (posojila upstream) treba presojati z vidika kogentnih splošnih pravil o ohranjanju kapitala, enako pa velja tudi za zavarovanja za posojila tretjih oseb, na primer bank. Finančna asistenca je dopustna le, kolikor ne pomeni prepovedanega vračila vložka. Izpostavljata tudi posebnosti, ki veljajo v primerih koncernsko povezanih družb.

Ključne besede: delniška družba; družba z omejeno odgovornostjo; posojilo; zavarovanje; prepovedana finančna asistenca.

\section{UVOD}

Finančna asistenca med družbo in imetniki njenih deležev lahko v načelu poteka v obeh smereh: tako, da imetnik deleža finančno asistira „svoji” družbi (finančna asistenca down-stream), ali pa tako, da družba finančno asistira svojemu družbeniku (finančna asistenca up-stream). Pod pojmom „,inančna asistenca” razumemo različne oblike prevzemanja obveznosti (družbe za imetnika deležev in obratno), predvsem v obliki zagotavljanja posojil ali pa v obliki zavarovanja za posojila, ki jih (družbi ali imetniku deležev) zagotovi kdo tretji, na primer poslovna banka.

* Dr. Saša Prelič, redni profesor, Pravna fakulteta, Univerza v Mariboru, Slovenija; sasa.prelic@ um.si.

** Dr. Marijan Kocbek, redni profesor, Pravna fakulteta, Univerza v Mariboru, Slovenija; marijan. kocbek@um.si.

This paper is written under support of the Croatian Science Foundation project no. 9366 „Legal Aspects of Corporate Acquisitions and Knowledge Driven Companies' Restructuring" and University of Rijeka project no. 13.08.1.2.01 „Protection of Beneficiary on the Croatian and European Financial Services Market". 
Za te posle veljajo nekatere pomembne omejitve, v obliki pravil korporacijskega prava o razmerjih med družbo in imetniki deležev, predvsem so relevantna pravila o ohranjanju kapitala. Te omejitve imajo namen preprečiti različna tveganja, predvsem $\mathrm{s}$ ciljem zaščite upnikov družbe.

Pravna problematika je zelo kompleksna, v nadaljevanju tega prispevka pa se želimo osredotočiti na položaje, ko družba finančno asistira v korist imetnika svojih deležev (finančna asistenca up-stream). Poskušali bomo analizirati, ali in pod katerimi pogoji je dopustno, da kapitalska družba - delniška družba ali družba z omejeno odgovornostjo - neposredno kreditira imetnika svojih deležev ali pa v breme svojega premoženja zavaruje njegove kreditne obveznosti, ki jih ima ta do dajalca kredita, in predvsem, kakšne pravne posledice nastopijo v primeru morebitnih kršitev pravil s tem v zvezi.

Pravne položaje obravnavamo s stališča slovenskega korporacijskega prava in aktualne sodne prakse. Ta problematika je, med drugim v luči urejanja razmerij v družbi Agrokor, d. d., tudi zelo aktualna.

\section{ZAS̆ČITA VEZANEGA KAPITALA KOT TEMELJNI POSTULAT PRAVA KAPITALSKIH DRUŽB}

Teorija prava kapitalskih družb temelji na načelu absolutne zaščite vezanega kapitala teh družb. V tej zvezi je relevantno predvsem vprašanje, koliko - če sploh - in v katerih položajih bi smela biti dopustna finančna asistenca kapitalske družbe njenemu družbeniku ter kakšne so posledice morebitne kršitve morebitne prepovedi finančne asistence. Osrednje vprašanje je torej, ali je dopustno, da kapitalska družba - ki ima svojo člansko strukturo in svoje upnike - sprejema finančne obveznosti v korist katerega (na primer večinskega) od svojih družbenikov, in kakšne so posledice, če morebitno prepoved krši.

$\mathrm{Za}$ pravilno razumevanje te problematike je najprej treba opredeliti splošne postulate pravne ureditve družb, ki so pravno organizirane kot kapitalske družbe. Slovenska pravna ureditev je $\mathrm{v}$ tem delu posnetek nemške.

Osrednja in temeljna značilnost vsake kapitalske družbe je, da imetniki njenih deležev (delničarji ali imetniki poslovnih deležev) za obveznosti družbe ne odgovarjajo, temveč odgovarja le družba sama, in to s tistim, kar ji pravno pripada, torej samo z lastnim premoženjem. Upnik kapitalske družbe lahko ob neizpolnitvi obveznosti v postopku izvršbe zoper družbo - dolžnika poseže samo po tistem, kar ji kot dolžniku njegove terjatve pravno pripada, tj. po njenem premoženju, ne more pa posegati po tistem, kar pravno pripada imetnikom njenih deležev.

Zato je temeljni postulat prava kapitalskih družb izražen $\mathrm{v}$ načelu, da je predpostavka za (1) nastanek (katerekoli) kapitalske družbe in tudi za (2) njen obstoj njena ustrezna premoženjska strukturiranost, vezani kapital pa je pravno absolutno zaščitena kategorija. Zaščita vezanega kapitala in zaščita vezanega premoženja sta osrednja instrumenta prava kapitalskih družb in sta namenjena varovanju interesa upnikov teh družb. Normativno se to izhodišče kaže $\mathrm{v}$ dveh sklenjenih sklopih „premoženjsko orientiranih” pravil, katerih namen je zaščita vezanega kapitala oziroma vezanega premoženja pred posegi imetnikov deležev. 


\subsection{Zagotavljanje kapitala z dolžnostjo vplačila vložkov}

Prvi sklop pravil zajema vsa tista pravila, ki naj bi - vsako posebej in vsa skupaj - zagotovila, da ustanovitelji kapitalske družbe že v fazi njene inkorporacije vanjo v obliki vložkov v (osnovni) kapital vnesejo konkretne premoženjske pravice, katerih realna ekonomska vrednost naj bi dosegla vsaj višino tako imenovanega osnovnega kapitala. Ta sklop pravil teorija korporacijskega prava imenuje ,pravila o zagotovitvi (zagotavljanju) kapitala".

$\mathrm{V}$ delniškem pravu - smiselno enako velja tudi pri družbah $\mathrm{z}$ omejeno odgovornostjo - mednje spadajo predvsem:

- pravila o prepovedi izdajanja deležev pod njihovo nominalno vrednostjo (prvi odstavek 173. in prvi odstavek 191. člena ZGD-1),

- pravila o statutarni publiciteti $\mathrm{v}$ zvezi s posebnimi ugodnostmi in ustanovitvenimi stroški (186. člen ZGD-1) ter s stvarnimi vložki in stvarnimi prevzemi (187. člen ZGD-1),

- pravila o poustanovitvi (188. člen ZGD-1),

- pravila o posebnem režimu vplačila delnic, kadar delniško družbo ustanavlja ena sama oseba (šesti odstavek 191. člena ZGD-1),

- pravila o dolžnosti sestaviti ustanovitveno poročilo, predvsem v zvezi z navedbo o prevzemu delnic za račun članov uprave oziroma nadzornega sveta družbe oziroma o tem, ali so bile zanje zagotovljene posebne ugodnosti (drugi odstavek 193. člena ZGD-1),

- pravila o vsebini in obsegu ustanovitvene revizije (195. člen ZGD-1),

- pravila o zagotavljanju oziroma dolžnosti vplačila vložka za prevzete delnice (prvi odstavek 199. v zvezi s četrtim odstavkom 191. člena ZGD-1),

- pravila o dolžnosti registrskega sodnika, da ob priglasitvi vpisa ustanovitve preveri pravilnost ustanovitvenih postopkov (200. člen ZGD-1), ter

- pravila o predpostavkah odškodninske odgovornosti ustanoviteljev in drugih oseb (203. in 204. člen ZGD-1).

Spoštovanje teh pravil povzroči, da kapitalska družba ob svojem nastanku že razpolaga z lastnim, od družbenikov pridobljenim, a hkrati od njih povsem neodvisnim in pravno ločenim premoženjem, katerega višina je vsaj enaka višini osnovnega kapitala.

\subsection{Ohranjanje kapitala s prepovedjo vračila vložkov}

Tudi če je bilo v družbo ob njeni ustanovitvi vneseno realno premoženje vsaj v višini osnovnega kapitala, pa ta okoliščina samodejno še ne zagotavlja celovite zaščite pravno priznanega interesa upnikov. Svojo jamstveno funkcijo lahko osnovni kapital izpolni le, če družba trajno (in ne le ob ustanovitvi) razpolaga s premoženjem v višini osnovnega kapitala.

Zato je nadalje uveljavljen še sklop pravil, ki omogočajo ohranjanje premoženja družbe ves čas njenega obstoja, torej do nastopa pravnega dejstva prenehanja oziroma „razpustitve” (na primer do trenutka sprejetja sklepa o prenehanju).

Ta sklop pravil teoretiki označujejo s sintagmo pravila o ohranjanju (vzdrževanju) 
kapitala.

V delniškem pravu med pravila za uresničitev načela ohranjanja kapitala - poleg bilančnopravnih - spadajo trije zaokroženi sklopi zakonskih pravil:

- absolutna prepoved kakršnekoli vrnitve oziroma obrestovanja vložka (prvi odstavek 227. člena ZGD-1),

- načelna prepoved pridobivanja lastnih delnic (247. člen ZGD-1) in

- pravilo, da je pred likvidacijo družbe dovoljeno med delničarje razdeliti le bilančni dobiček (osmi odstavek 230. člena ZGD-1).

V pravu družb z omejeno odgovornostjo velja smiselno enako; uveljavljeno je pravilo, da družbenikom ni dopustno izplačati tistega premoženja, ki je potrebno za ohranitev osnovnega kapitala in vezanih rezerv (prvi odstavek 495. člena ZGD-1).

Namen teh pravil je ustvariti pogoje, da bi družba ne le ob ustanovitvi, temveč ves čas svoje pravne eksistence razpolagala vsaj s premoženjem, katerega višina (vrednost) dosega višino njenega osnovnega kapitala (oziroma vezanih rezerv).

Za pravilno razumevanje pomena teh pravil je treba izhajati iz ugotovitve, da pravila, ki so namenjena zaščiti premoženja, tega ne morejo ščititi pred tistimi tveganji, na katera je vpliv prava omejen, kot so tveganja, ki so posledica dogodkov v zvezi s poslovnimi aktivnostmi družbe (na primer izguba, kot negativni poslovni izid) ali ki so povezana z naravnimi dogodki (na primer požar, povodenj ali druge katastrofe, ki na primer uničijo vsa osnovna sredstva družbe in s tem prizadenejo njeno premoženje). Ker je jasno, da pravna ureditev teh tveganj s prepovednimi normami ne more izključiti, je jasno tudi, da je težišče pravil o ohranjanju kapitala nekje drugje.

Namen teh pravil je zavarovati premoženje družbe pred imetniki deležev družbe kot njenimi „ekonomskimi lastniki” oziroma ,gospodarji njene pravne usode”. Pravila o ohranjanju kapitala preprečujejo, da bi si imetniki deležev - pri uresničevanju svoje korporacijske pravice, pridobljene na temelju vplačila vložka - (v obdobju po ustanovitvi družbe) razdelili premoženje družbe, ga zmanjšali in tako negativno vplivali na finančne zmožnosti družbe, da pravilno (tj. pravočasno in popolno) izpolnjuje svoje obveznosti. ${ }^{1}$

Pravila o ohranjanju kapitala - predvsem s prepovednimi normami - varujejo premoženje družbe tako, da v obdobju po ustanovitvi družbe prepovedujejo razdelitev premoženja med imetnike deležev. Osrednje pravilo je izraženo v (načelni) prepovedi vrnitve vložkov imetnikom deležev (prvi odstavek 227. člena ZGD-1). V delniškem pravu je ohranjanje kapitala posebej poudarjeno tudi v določbi osmega odstavka 230. člena ZGD-1, po kateri je delničarjem pred likvidacijo družbe (to pomeni pred sprejetjem sklepa o prenehanju družbe) dovoljeno razdeliti izključno le bilančni dobiček.

Zakonska zahteva po ohranjanju kapitala se ne nanaša zgolj na osnovni kapital, temveč tudi na 1) kapitalske in 2) zakonske rezerve, torej na ves vezani kapital družbe. Vezani kapital tvorijo torej:

1 Treba je namreč upoštevati, da bi se dejstvo, da je bilo v družbo ob ustanovitvi vneseno realno premoženje, izkazalo za povsem brezpredmetno, če bi po njeni ustanovitvi imetniki njenih deležev smeli po prosti presoji (in na različnih pravnih podlagah) in brez omejitev posegati po tem njenem premoženju. 
- osnovni kapital in

- vezane rezerve, ki so po določbi desetega odstavka 64. člena ZGD-1 sestavljene iz kapitalskih in zakonskih rezerv.

Posebej je to izraženo tudi v pravu družb z omejeno odgovornostjo.

\subsection{Zaščita vezanega kapitala}

Pravo kapitalskih družb ščiti vezani kapital družbe. Njegova zaščita jamči ohranjanje tistega premoženja družbe, ki je (računovodsko) v kapitalu izražen v njegovih vezanih kategorijah - vezanem kapitalu. Zaščitna funkcija je v tem, da se ta kapital lahko uporabi (sprosti) izključno le za uresničevanje zakonsko določenih namenov, med katere pa ne spada izplačevanje dividend ali drugih izplačil imetnikom deležev. Premoženje, ki ima (računovodsko) kritje v vezanem kapitalu družbe - dokler družba obstaja -, zato ostaja zunaj dosega imetnikov deležev in je na neki način (pred njimi) „zaklenjeno” v družbi. To premoženje je nekakšno ,vezano” premoženje, ker ne sme biti razdeljeno imetnikom deležev. S stališča upnikov družbe omogoča povečevanje jamstvenega potenciala, s katerim družba odgovarja za svoje obveznosti.

Pravila o zaščiti vezanega kapitala tvorijo skladen sistem, ki naj bi (kot koherentna celota) zagotovil, da med imetnike deležev ne bo razdeljena niti ena sama enota tistega premoženja družbe, ki ima v kapitalu kritje v njegovih vezanih kategorijah. Gre torej za absolutno prepoved izplačil iz vezanega premoženja, kar velja - sicer različno intenzivno - pri obeh pravnoorganizacijskih oblikah kapitalskih družb. Ta pravila kot celota zagotavljajo, da družba oblikuje, dopolnjuje in vzdržuje lastno premoženje, katerega funkcija je tudi, da z njim odgovarja za svoje obveznosti.

\subsection{Kogentno določena dovoljena izplačila imetnikom deležev}

Zaradi zaščite interesa upnikov je za pravo kapitalskih družb (za delniško pravo pa še posebej) značilno, da na prisilen način opredeljuje katalog prejemkov, ki jih imetniki deležev sploh smejo prejeti od družbe na temelju udeležbe v korporacijskem razmerju (causa societatis), oziroma, obrnjeno, katalog izplačil, ki jih družba sme opraviti v korist imetnikov deležev na udeležbenem temelju. Družbi je namreč dovoljeno $\mathrm{v}$ breme svojega premoženja in $\mathrm{v}$ korist imetnikov deležev opraviti le izrecno dovoljena plačila. Tako sme delniška družba delničarjem (do sprejetja sklepa o prenehanju družbe) izplačati le dividendo (osmi odstavek 230. člena ZGD-1), pri družbah z omejeno odgovornostjo pa je izplačilna prepoved nekoliko ožja in se nanaša na osnovni kapital in vezane rezerve. Premoženje, potrebno za ohranitev osnovnega kapitala in vezanih rezerv, se družbenikom ne sme izplačati (prvi odstavek 495. člena ZGD-1).

Za nadaljevanje razprave je zato relevantna naslednja teza: vsa plačila (tj. prejemki), ki so jih delničarji od družbe prejeli v nasprotju z zakonom (ki torej niso dividenda), pri družbenikih družb z omejeno odgovornostjo pa tista, ki so opravljena v breme vezanega kapitala (osnovnega kapitala ali vezanih rezervah), so nezakonita in so zato prepovedana. Prepovedana so, ker se šteje, da so opravljena $v$ breme vezanega 
kapitala oziroma da posegajo v ta vezani kapital, ki je - kot je bilo razloženo zgoraj - „nedotakljiv” in ki je funkcionalni ščit interesa upnikov. Učinkujejo kot vračilo vložka. Ob morebitni kršitvi se uporabi pravilo, po katerem morajo imetniki deležev vsako táko plačilo družbi vrniti in s tem na novo oblikovati vezani kapital, ki je bil prikrajšan s prepovedanim plačilom.

To je racionalno jedro oziroma ekonomsko ozadje načelne določbe prvega stavka 233. člena oziroma prvega odstavka 496. člena ZGD-1.

\subsection{Prepovedano vračilo vložka}

Družbi je torej prepovedano vrniti (ali obrestovati) vložke. Tveganje je, da se prepoved prekrši, saj bi lahko vložke vrnila na različne načine: bodisi z enostranskim prenosom premoženja družbeniku, ne da bi sama od njega prejela kakršnokoli nasprotno izpolnitev (odkrito vračilo vložka), bodisi bi vložek vrnila posredno, na podlagi sklenitve in izpolnitve dvostranskega pravnega posla, ki ga skleneta družba in imetnik deležev, pri katerem družba sicer sprejme nasprotno izpolnitev, vendar pa je pri tem podano očitno nesorazmerje med izpolnitvami (prikrito vračilo vložka).

\subsubsection{Prikrito vračilo vložka}

Prikrito vračilo vložka zajema vsa dejanska stanja, ki sicer dobesedno ne pomenijo nujno vračila vložka, a glede na razloge in namen, ki ga imajo, dejansko učinkujejo kot vračilo vložka. ${ }^{2}$ Za prikrita vračila vložka je značilno, da praviloma temeljijo na dvostranskih pravnih poslih, ki jih družba sklepa z imetniki deležev, pri čemer pa je obveznost družbe $\mathrm{v}$ nesorazmerju $\mathrm{z}$ obveznostjo imetnika deležev (obveznost družbe po vrednosti presega prejeto nasprotno izpolnitev - objektivno nesorazmerje), posledica česar je zmanjšanje premoženja družbe ali preprečitev njegovega povečanja. Imetnik deležev je deležen neke posebne koristi, ki se navzven ne kaže kot (pravo in dovoljeno) izplačilo dobička, premoženje družbe pa se zmanjšuje.

Za prikrita vračila vložka je značilno, da:

- $\quad$ so posledica pravnih poslov, ki jih poslovodstvo družbe ne bi sklenilo s tretjimi osebami pod takšnimi pogoji, kot jih sklene z imetnikom deležev,

- na podlagi takšnih pravnih poslov imetnik deležev (oziroma z njim povezane osebe) prejme neko posebno premoženjsko korist.

$\mathrm{Na}$ takšnem pojmovanju načela ohranitve kapitala temelji - kot dosleden posnetek nemškega AktG - tudi slovenska korporacijska zakonodaja, ki izrecno opredeljuje prikrito vračilo vložka in ga prepoveduje (prvi odstavek 227. člena ZGD1). V skladu s tretjim odstavkom 227. člena ZGD-1 so nedopustna plačila za dajatve ali storitve delničarja ali z njim povezanih družb v višini, ki presega njihovo pravo vrednost, ne glede na to, ali je bilo plačilo dano delničarju ali z njim povezani družbi ali tretjemu po naročilu delničarja.

Najbolj tipični primeri prikritih vračil vložka so:

- plačilo za nedopustno pridobitev lastnih deležev;

2 Glej pri Hüffer, U., Aktiengesetz Kommentar; Beck, München, 2004, stran 286. 
- prodaja blaga ali oprava storitev po nabavni vrednosti oziroma po vrednosti, ki zadošča le za pokritje stroškov;

- plačilo za umik izpodbojne tožbe, ki jo je zoper sklepe skupščine vložil (ali napovedal) imetnik deležev;

- zagotovitev posojila imetniku deležev pod pogoji, ki so ugodnejši od tržnih: če družba imetniku deležev zagotovi posojilo pod enakimi pogoji, kot bi ga zagotovila tretji osebi, imetnik deležev ne prejme posebne koristi, ki bi bila prepovedana. Gre pač za kreditni posel, kot bi ga družba sklenila tudi s tretjo osebo. Če pa družba pri takšnem poslu imetnika deležev obravnava ugodneje - mu zagotovi brezobrestno posojilo ali posojilo, za katero je sicer dolžan plačevati obresti, vendar je dogovorjena obrestna mera nižja od tržne, ali če družba za dano posojilo sploh ne zahteva ustreznega zavarovanja oziroma če imetniku deležev zagotovi posojilo, ki ga tretji osebi v nobenem primeru ne bi zagotovila -, se premoženje družbe zmanjša, saj v zameno za zagotovitev posojila ne prejme ustreznega nadomestila. Takšno posojilo je prepovedano vračilo vložka; ${ }^{3}$

- zagotovitev zavarovanj za obveznosti imetnika deležev do tretjih oseb, in končno: tudi zavarovanja, ki jih družba zagotovi v korist imetnika deležev (torej jamstva, ki jih prevzame za obveznosti imetnika deležev), se ne glede na njihovo pravno obliko obravnavajo kot prikrita vračila vložkov, če jih družba v nobenem primeru ne bi zagotovila tretji osebi ali če v zameno za ustanovitev takšnega zavarovanja ne prejme ustreznega nadomestila, kot se sicer zaračunava pri tovrstnih poslih v okviru bančnega poslovanja. Družba $\mathrm{v}$ takšnih primerih zagotovi imetniku deležev ugodnost na svoje stroške oziroma v breme svojega premoženja. V literaturi se posebej poudarja, da prepovedano dejanje lahko pomeni že sama zagotovitev zavarovanja, ne šele morebitna unovčitev takšnega zavarovanja. ${ }^{4}$

\subsubsection{Pravne posledice kršitve prepovedi vračila vložka}

Vse oblike vračila vložka so prepovedane.

Takšno enotno pojmovanje je sprejeto glede prepovedi vračila vložka, pri pravnih

3 Po enakih pravilih se obravnavajo tudi primeri, ko družba imetniku deležev omogoči odlog plačila njegove obveznosti, saj to zanjo pomeni povečano tveganje. Takšno posredno kreditiranje bi bilo dopustno (ne bi bilo v nasprotju s prepovedjo vračila vložka) le, če bi bila družba pripravljena tudi tretji osebi pod enakimi pogoji omogočiti odlog plačila in če bi v zameno prejela primerno nadomestilo.

4 Hüffer, U., Aktiengesetz Kommentar; Beck, München, 2004, stran 288. Prepovedano vračilo vložka pa je podano tudi, če družba zavaruje terjatve imetnika deležev do tretje osebe, ki ji je zagotovil posojilo. Družba na ta način imetniku deležev zagotovi posebno korist, ki se šteje za vračilo vložka, in sicer s tem, da minimalizira njegovo tveganje pri takšnem poslu. Tveganje nevračila posojila, ki ga je imetnik deležev zagotovil tretji osebi, prevzame namreč družba, $s$ čimer ogrozi svoje premoženje. Tudi v takšnem primeru se za prepovedano dejanje šteje že zagotovitev takšnega zavarovanja, ne šele morebitna izpolnitev obveznosti, ki jo je družba s takšnim pravnim poslom prevzela. Znotraj koncernskih razmerij pa seveda enako velja tudi, če družba zagotovi zavarovanje za obveznosti sestrske koncernske družbe. 
posledicah prepovedanih vračil vložka pa je nekaj razlik, in sicer predvsem glede pravnih posledic odkritega in prikritega vračila vložka. Določene razlike nastopijo tudi, ko se v dejansko stanje prepovedanega vračila vložka vključujejo tretje osebe (bodisi na strani družbe bodisi na strani imetnika deležev).

- Ničnost pravnega posla pri odkritem vračilu vložka

Odkrita vračila vložkov so nedopustna, posledica pa je ničnost pravnega posla (kot celote), ki nasprotuje temeljnemu načelu prepovedi vračila vložka. Ničen je tako zavezovalni pravni posel (kavzalni pravni posel), ki je podlaga za dejansko vračilo vložka, kot razpolagalni pravni posel. ${ }^{5}$

- Usoda pravnega posla pri prikritem vračilu vložka

Glede tega vprašanja se v literaturi pojavljata dve stališči:

- Pravni posel, ki je podlaga za prikrito vračilo vložka, je nedopusten in ima enako usodo kot pravni posel, na podlagi katerega pride do odkritega vračila vložka, torej ničnost zavezovalnega in razpolagalnega pravnega posla:

prikrito vračilo vložka je (praviloma) posledica pravnih poslov med družbo in imetnikom deležev, pri katerih je podano objektivno nesorazmerje med pogodbenimi obveznostmi (v korist imetnika deležev) - izpolnitev družbe po vrednosti presega nasprotno izpolnitev. Pravni posel, ki je podlaga za nastanek takšne obveznosti družbe (torej zavezovalni pravni posel), je ničen (enako kot v primeru odkritega vračila vložka). Družbi je izpolnitev takšne obveznosti prepovedana, zato poslovodstvo obveznosti ne sme izpolniti.

Zagovorniki se sklicujejo na strogost zakonskih določb o ohranitvi kapitala, drugačno pojmovanje naj bi bilo v nasprotju z njihovim namenom. ${ }^{6}$

Objektivnega nesorazmerja med pogodbenimi obveznostmi, ki ima podlago v sklenjenem (zavezovalnem) pravnem poslu, ni mogoče sanirati, ker bi tak pravni posel pomenil nekaj drugega od tistega, kar sta stranki prvotno želeli. Zakon prikrita vračila vložka prepoveduje (enako kot odkrita vračila), ne omogoča pa posegov v vsebino (na primer določitev nove vrednosti) pravnega posla, zaradi česar je zavezovalni pravni posel ničen.

Družbi je izpolnitev obveznosti, prevzete z zavezovalnim pravnim poslom, prepovedana. Če izpolnitev kljub temu opravi, je tudi razpolagalni pravni posel - izpolnitev obveznosti - ničen. Če v zameno za svojo izpolnitev ne prejme nikakršne nasprotne izpolnitve s strani delničarja (odkrito vračilo

5 Hüffer, U., Aktiengesetz Kommentar; Beck, München, 2004, stran 292. Zakonska prepoved vračila vložka $\mathrm{v}$ prvi vrsti prepoveduje prepovedana izplačila $\mathrm{v}$ breme vezanega premoženja družbe. V nekaterih primerih pa je lahko dejansko stanje prepovedanega vračila vložka podano že pred kakršnimkoli izplačilom iz vezanega premoženja družbe - zagotovitev zavarovanja za obveznosti delničarja, ki jih ima (delničar) do tretje osebe. V takšnem primeru je dejansko stanje vračila vložka podano že v trenutku zagotovitve zavarovanja, ne šele takrat, ko se premoženje družbe dejansko zmanjša (zaradi dolžnosti plačila delničarjeve obveznosti).

6 „Die gegenteilige Ansicht, den Verpflichtungsgrund nicht oder nicht insgesamt der Nichtigkeitfolge zu unterwerfen, läßt sich jedoch mit der strengen Kapitalbindung nicht vereinbaren. Außerdem würde dies nicht der Regelung des \$62 entsprechen. Denn ein wirksamer Vertrag stünde dem Rückgewäranspruch entgegen: Das kann also vom Gesetz nicht gewollt sein”. Tako Henze, H., Aktiengesetz Großkommentar; deGruyter, 2001, stran 202; smiselno enako tudi Hüffer, U., Aktiengesetz Kommentar; Beck, München, 2004, stran 292. 
vložka), je ničnost razpolagalnega pravnega posla edina primerna sankcija. Tudi če družba za izvršeno vračilo vložka prejme (po vrednosti) neprimerno nasprotno izpolnitev (tj. prikrito vračilo vložka), je razlika $\mathrm{z}$ odkritim vračilom vložka samo v naslovu. Kot argument za ničnost razpolagalnega pravnega posla se (v obeh primerih) navaja doseganje maksimalnega varstva premoženja družbe. ${ }^{7}$

- Pravni posel, ki je podlaga za prikrito vračilo vložka, je sicer v nasprotju s temeljnim načelom prepovedi vračila vložka, vendar je sankcija ničnosti pretirana; posel je veljaven:

ničnost zavezovalnega in razpolagalnega pravnega posla, ki je podlaga za prikrito vračilo vložkov, je po mnenju drugih pretirana sankcija, prav tako naj bi ničnost pravnega posla kot celote ne ustrezala namenu normativnega urejanja. ${ }^{8}$ Za ponovno vzpostavitev (sicer porušenega) premoženjskega stanja družbe je primernejša izravnava pogodbenih obveznosti (na primer prilagoditev cene). Pravna podlaga za zahtevek družbe na izenačitev (izravnavo) pogodbenih obveznosti pa je korporacijskopravni zahtevek po 233. členu ZGD-1 (oziroma po prvem odstavku 496. člena ZGD-1 za družbe $\mathrm{z}$ omejeno odgovornostjo). Imetnik deležev lahko vztraja pri izpolnitvi obveznosti s strani družbe, pri čemer se seveda strinja tudi s povečanjem svoje obveznosti do družbe, družba pa te pravice nima, ker bi sicer imetnik deležev moral izpolniti več, kot se je zavezal s pravnim poslom.

Sklenemo lahko z ugotovitvijo, da pravni posel prikritega vračila vložka dejansko v manjši meri nasprotuje načelu prepovedi vračila vložka (v primerjavi s poslom, ki je podlaga za odkrito vračilo vložka), vendar so prepričljivejši argumenti tistih, ki zagovarjajo tezo, da je posledica kršitve pravil o prepovedi vračila vložka tudi pri prikritih vračilih ničnost tako zavezovalnega kot razpolagalnega posla. Po našem to stališče velja še zlasti pri tistih pravnih transakcijah, pri katerih je z izravnalno sankcijo nemogoče doseči vzpostavitev prejšnjega stanja. Zlasti to velja pri poslih, pri katerih prejemnik koristi sam ni opravil nobene nasprotne izpolnitve. Pri teh poslih lahko že pojmovno ekvivalenco vzpostavi le zahteva, da prejeti predmet (na primer predmet zavarovanja) vrne.

\subsubsection{Uveljavljanje vračila prepovedanih plačil s korporacijskim vrnitvenim zahtevkom}

Če družba izvrši plačila, ki nasprotujejo prepovedi vračila vložka, in imetniku deležev vrne vložek, gre za prepovedano vračilo vložka, ne glede na to, ali je to odkrito ali prikrito. Imetnik deležev je družbi zavezan vrniti izplačila, ki jih je prejel v nasprotju z zakonom (prvi stavek prvega odstavka 233. člena ZGD-1), razen če zakon določa drugače (primerjaj drugi stavek prvega odstavka 233. člena ZGD-1). ${ }^{9}$

7 Henze, H., Aktiengesetz Großkommentar; deGruyter, 2001, stran 204.

8 Schmidt, K., Gesellschaftsrecht; Heymanns, 1997, strani 898 in 899.

9 V drugem stavku prvega odstavka 233. člena ZGD-1 je uzakonjena (edina) izjema od splošnega načela dolžnosti vračila prepovedanih plačil. Dolžnost vračila prepovedanih plačil se načeloma 
Praktično enako pravilo velja tudi v pravu družb $\mathrm{z}$ omejeno odgovornostjo (prvi odstavek 496. člena ZGD-1).

Za vračilo je družbi priznan poseben korporacijski zahtevek za vračilo prepovedanih plačil (korporacijski vrnitveni zahtevek). V materialnopravnem razmerju je njegov nosilec družba, ki je v breme svojega vezanega kapitala opravila prepovedano plačilo. Zahtevek je specialen zahtevek korporacijske pravne narave in je zanj značilno, da je povsem neodvisen od katerihkoli drugih morebitnih zahtevkov. Družba s tem zahtevkom, ki ga naperi proti imetniku deležev, ki mu je bila izplačala prepovedano plačilo, uveljavlja povračilo tega, kar je plačala, v svoje premoženje, $\mathrm{s}$ čimer vzpostavi prvotno premoženjsko stanje ter sanira primanjkljaj v vezanem kapitalu. Uveljavljanje korporacijskega vrnitvenega zahtevka v razmerju do imetnika deležev ne predpostavlja obstoja okoliščin, ki so sicer nujne za uveljavljanje zahtevkov na drugih podlagah. Za to, da družba korporacijski vrnitveni zahtevek uveljavi, ni merodajna dobro- oziroma slabovernost, morebitna odgovornost imetnika deležev ali družbe in drugo. V nemškem pravu ni dvoma, da je uveljavljanje korporacijskega vrnitvenega zahtevka neodvisno od splošnih predpostavk, kot jih za uveljavljanje drugih zahtevkov predpisuje civilno pravo, zahtevek pa je po učinkih izenačen z zahtevkom družbe za vplačilo vložka. ${ }^{10}$ Položaj, ki nastane, če družba imetniku deležev izplača (izpolni) prepovedano plačilo, je namreč enak, kot če ta vložka sploh ne bi bil vplačal. Za zastaranje tega zahtevka je določen daljši, specialni zastaralni rok (tretji odstavek 233. člena ZGD-1), predvsem pa imetnik deležev svojega morebitnega obligacijskega zahtevka zoper družbo ne sme pobotati s korporacijskim vrnitvenim zahtevkom družbe (četrti odstavek 233. člena ZGD-1). ${ }^{11}$

nanaša na vsa plačila, ki jih delničar prejme od družbe v nasprotju z zakonskimi določbami. Izjema so plačila, ki jih delničar v dobri veri prejme v obliki dividend. Samo takšnih plačil ne zadeva dolžnost vrnitve.

10 Lutter, M., Kölner Kommentar zum Aktiengesetz; Heymanns, Köln-Berlin-Bonn-München, 1988, komentar § 62 AktG, r. št. 5; Bayer, W., Münchener Kommentar zum Aktiengesetz; Beck/ Vahlen, München, 2003, komentar § 62 AktG, r. št. 8.

11 V slovenski sodni praksi se je pojmovanje pravne narave korporacijskega vrnitvenega zahtevka nekoliko spreminjalo, čeprav je pravna teorija ves čas zagovarjala stališče o njegovi posebni (specialni) pravni naravi; glej na primer pri Kocbek, M.,: Zakon o gospodarskih družbah s komentarjem; GV Založba, Ljubljana, 2012, I knjiga, stran 670, ki je enako stališče zagovarjal tudi po nadomestitvi ZGD z ZGD-1 (2006): Veliki komentar ZGD-1; GV Založba, Ljubljana, 2006, II. knjiga, strani 218, 266, 267. Sodna praksa je sprva korporacijski vrnitveni zahtevek (oziroma posledice kršitve prepovedi prepovedanih plačil imetnikom deležev) povezovala s pravili obligacijskega prava o ničnosti pravnih poslov; glej na primer sodbo VSRS, opr. št. III Ips 109/2011. Vsako dilemo o tem, kakšna je normativna vsebina zakonske dolžnosti vrnitve prepovedanih plačil (in torej pravna narava korporacijskega vrnitvenega zahtevka), je dokončno odpravila novela ZGD-1B, ki je v 233. členu (prej 230. člen ZGD) jasno poudarila samostojno in od drugih pravil neodvisno pravno naravo tega zahtevka; podrobneje Kocbek, M., Prelič, S., Zakon o gospodarskih družbah (ZGD-1) z novelama ZGD-1A in ZGD-1B; GV Založba, Ljubljana, 2008, strani 62-70. Zato se je spremenilo tudi pojmovanje tega zahtevka v sodni praksi; glej sodbo VSRS, opr. št. III Ips 79/2017. Tudi Vrhovno sodišče RS torej izrecno priznava samostojno naravo korporacijskega vrnitvenega zahtevka. 
V primerjalni ${ }^{12}$ in tudi slovenski literaturi ${ }^{13}$ je enotno sprejeto stališče, da je zahtevek družbe za vrnitev prepovedanih plačil neodvisen od katerihkoli drugih morebitnih zahtevkov oziroma da je to samostojni korporacijski vrnitveni zahtevek. Nemški avtorji dosledno in posebej poudarjajo, da ,,aktienrechtliche Anspruch verdrängt Ansprüche aus Kondiktion und Vindikation", ${ }^{14}$ kar neposredno kaže na neodvisnost in samostojno naravo tega zahtevka.

Vsa dostopna literatura s področja korporacijskega poudarja, da uveljavljenje tega zahtevka v razmerju do delničarja ne predpostavlja obstoja okoliščin, ki so sicer nujne za uveljavljanje zahtevkov na drugih podlagah. Za to, da družba korporacijski vrnitveni zahtevek $\mathrm{v}$ razmerju do delničarja uveljavi, tako ni merodajna dobrooziroma slabovernost, morebitna odgovornost delničarja ali družbe in drugo. Tako v nemškem pravu avtorji trdijo, da je uveljavljanje korporacijskega vrnitvenega zahtevka povsem neodvisno od splošnih predpostavk, kot so za uveljavljanje drugih zahtevkov predpisane v civilnem pravu. ${ }^{15}$ Avstrijski pisec Saurer je celo izrecno zapisal, da je zahtevek samostojen in neodvisen od temeljnih principov prava neupravičene pridobitve. ${ }^{16}$ Pravnodogmatično literatura ta korporacijski vrnitveni zahtevek enači z zahtevkom družbe za vplačilo vložka oziroma mu pripisuje enak funkcionalni pomen. ${ }^{17}$

Slovenska normativna ureditev je enaka ureditvi v primerjalnem pravu. ZGD-1

12 To stališče je $\mathrm{v}$ primerjalnopravni literaturi povsem nesporno. Za ilustracijo glej navedbe naslednjih vodilnih teoretikov: Henze, H., Aktiengesetz Großkommentar; deGruyter, Berlin, 2000, komentar $\S 62$ AktG, r. št. 11; Bayer, W., Münchener Kommentar zum Aktiengesetz; Beck/Vahlen, München, 2003, komentar $§ 62 \mathrm{AktG,} \mathrm{r.} \mathrm{št.} \mathrm{7;} \mathrm{Lutter,} \mathrm{M.,} \mathrm{Kölner} \mathrm{Kommentar} \mathrm{zum}$ Aktiengesetz; Heymanns, Köln-Berlin-Bonn-München, 1988, komentar $\S 62$ AktG, r. št. 4; Hüffer, U., Aktiengesetz Kommentar; Beck, München, 2004, komentar $§ 62$ AktG, r. št. 2.

Za avstrijsko pravo enako Artmann, E., Aktiengesetz Kommentar; Manz, Wien, 2004, komentar $\S 56$ AktG, r. št. 4 ter Saurer, U., Kommentar zum Aktiengesetz; Linde, Wien, 2003, komentar $\S 56 \mathrm{AktG}, \mathrm{r}$. št. 8.

13 Kobal, A.: Pravna narava zahtevka delniške družbe za vračilo prepovedanega vračila vložka, PiD, 2/2008, stran 210; Kocbek, M., v Velikem komentarju ZGD-1; GV Založba, Ljubljana, 2007, II. knjiga, stran 267.

14 Artmann, E., Aktiengesetz Kommentar; Manz, Wien, 2004, komentar § 56 AktG, r. št. 4.

15 Lutter, M., Kölner Kommentar zum Aktiengesetz; Köln-Berlin-Bonn-München, 1988, komentar $\S 62$ AktG, r. št. 4, izrecno pravi: ,, Tatbestandselemente anderer Normen (insbesondere $\$ \S 812$ ff., 823 ff BGB) finden keine Anwenduntg. Der Anspruch is von einem Verschulden unabhängig. " Povsem enako stališče zastopa Bayer, W., Münchener Kommentar zum Aktiengesetz; Beck/ Vahlen, München, 2003, komentar $\S 62$ AktG, r. št. 7, kjer pravi: „Die Verpflichtung zur Rückgewähr besteht somit unabhängig von einem Verschulden des Empfängers und trägt nicht die Schwachen der $\$ \S 814,817,817$ BGB in sich."

16 Saurer, U., Kommentar zum Aktiengesetz; Linde, Wien, 2003, komentar § 56 AktG, r. št. 8, kjer pravi: „Der Anspruch der Gesellschaft auf Rückzahlung der verbotswidrug empfangenen Leistung nach \$ 56 ist eigenständiger, aktienrechtlicher Natur und ermöglicht die Rückforderung der Leistung unabhängig von Bereicherungsgrundsätzen."

17 Lutter, M., Kölner Kommentar zum Aktiengesetz; Heymanns, Köln-Berlin-Bonn-München, 1988, komentar § 62 AktG, r. št. 5; Bayer, W., Münchener Kommentar zum Aktiengesetz; Beck/ Vahlen, München, 2003, komentar § 62 AktG, r. št. 8; Henze, H., Aktiengesetz Großkommentar; deGruyter, Berlin, 2000, komentar § 62 AktG, r. št. 11. 
se sicer neposredno zgleduje po določbah $\S 62$ nemškega zakona o delnicah (AktG), ${ }^{18}$ enaka pa je tudi ureditev v avstrijskem delniškem pravu (glej § $56 \mathrm{AktG}){ }^{19}$ Po določbi prvega odstavka 233. člena ZGD-1 (prej 230. člena ZGD) morajo delničarji družbi vrniti plačila, ki so jih od nje prejeli v nasprotju s tem zakonom. Nadaljnja specifika korporacijskega vrnitvenega zahtevka je, da ga lahko - v svojem imenu in za račun družbe, kar pomeni, da je nosilec zahtevka $\mathrm{v}$ materialnopravnem razmerju vedno izključno družba ${ }^{20}$ - uveljavljajo tudi delničarji, katerih skupni deleži dosegajo vsaj desetino osnovnega kapitala ali katerih skupni najmanjši emisijski znesek dosega vsaj $400.000 €$ (tretji stavek prvega odstavka 233. člena ZGD-1), lahko pa ga uveljavljajo tudi upniki, če jih družba ne more poplačati (drugi odstavek 233. člena ZGD-1). Zahtevek se vedno naperi proti tistim, v korist katerih je bilo opravljeno prepovedano plačilo. Korporacijski vrnitveni zahtevek učinkuje v tem smislu kot sankcija za prejem prepovedanega plačila. ${ }^{21}$

Glede aktivne legitimacije: pravico zahtevati vračilo prepovedanih plačil le družba, ki je v razmerju do prejemnika prepovedanega plačila $\mathrm{v}$ obliki prepovedanega vračila vložka torej upnik. Zahtevek za vračilo prepovedanih plačil v materialnem smislu pripada samo družbi, saj je posledica prepovedanih izplačil zmanjšanje premoženja družbe, ki pa je predmet varstva.

Od zahtevka (v materialnem smislu) je treba razlikovati (samo) pravico do uveljavljanja zahtevka za vračilo prepovedanih plačil. Pravico do uveljavljanja zahtevka ima načeloma družba, v nekaterih primerih pa se priznava tudi upnikom družbe (drugi odstavek 233. člena ZGD-1) in manjšinskim delničarjem družbe (tretji

$18 \S 62$ nemškega AktG se glasi:

„(1) Die Aktionäre haben der Gesellschaft Leistungen, die sie entgegen den Vorschriften dieses Gesetzes von ihr empfangen haben, zurückzugewähren. Haben sie Beträge als Gewinnanteile bezogen, so besteht die Verpflichtung nur, wenn sie wußten oder infolge von Fahrlässigkeit nicht wußten, daß sie zum Bezug nicht berechtigt waren.

(2) Der Anspruch der Gesellschaft kann auch von den Gläubigern der Gesellschaft geltend gemacht werden, soweit sie von dieser keine Befriedigung erlangen können. Ist über das Vermögen der Gesellschaft das Insolvenzverfahren eröffnet, so übt während dessen Dauer der Insolvenzverwalter oder der Sachwalter das Recht der Gesellschaftsgläubiger gegen die Aktionäre aus.

(3) Die Ansprüche nach diesen Vorschriften verjähren in zehn Jahren seit dem Empfang der Leistung. § 54 Abs. 4 Satz 2 findet entsprechende Anwendung."

$19 \S 56$ avstrijskega AktG se glasi:

„(1) Die Aktionäre haften den Gläubigern für die Verbindlichkeiten der Gesellschaft, soweit sie entgegen den Vorschriften dieses Bundesgesetzes Zahlungen von der Gesellschaft empfangen haben. Dies gilt nicht, soweit sie Beträge in gutem Glauben als Gewinnanteile bezogen haben.

(2) Ist über das Vermögen der Gesellschaft der Konkurs eröffnet, so übt während dessen Dauer der Masseverwalter das Recht der Gesellschaftsgläubiger gegen die Aktionäre (Abs. 1) aus.

(3) Die Gesellschaft kann Beträge nicht zurückfordern, die Aktionäre in gutem Glauben als Gewinnanteile bezogen haben.

(4) Die Ansprüche nach diesen Vorschriften verjähren in fünf Jahren seit dem Empfang der Zahlung."

20 Lutter, M., Kölner Kommentar zum Aktiengesetz; Heymanns, Köln-Berlin-Bonn-München, 1988 , komentar $§ 62$ AktG, r. št. 6.

21 Lutter, M., Kölner Kommentar zum Aktiengesetz; Heymanns, Köln-Berlin-Bonn-München, 1988, komentar § 62 AktG, r. št. 8. 
stavek prvega odstavka 233. člena ZGD-1), v pravu družb z omejeno odgovornostjo pa lahko zahtevek kot actio pro socio uveljavlja vsak družbenik, na način in pod pogoji, določenimi v 503. členu ZGD-1.22

Glede pasivne legitimacije: ker se prepoved vračila vložka nanaša na razmerje med družbo in imetniki njenih deležev, sta naslovnika zakonske prepovedi družba in imetnik deležev (upravičen je le do izplačil iz premoženja družbe, ki niso izvršena v nasprotju s temeljno prepovedjo vračila vložka). Pri tem ni pomembno, ali je plačilo, ki pomeni vračilo vložka, prejel neposredno od družbe ali posredno od tretje osebe, ki je plačilo opravila sicer v lastnem imenu, vendar za račun (v breme premoženja) družbe.

$\mathrm{V}$ nekaterih primerih je glede na bistvo in cilje temeljnega načela ohranitve kapitala določena izplačila, ki jih družba sicer opravi v korist tretjih, vendarle treba obravnavati kot izplačila imetniku deležev in jih šteti za prepovedana vračila vložka. Ker se v specifičnih primerih izplačila tretji osebi lahko štejejo za vračilo vložka imetniku deležev, se $\mathrm{v}$ tej zvezi seveda zastavlja tudi vprašanje o dopustnosti uveljavljanja korporacijskega zahtevka za vračilo prepovedanih plačil od tretjih oseb, ki so vpletene v dejansko stanje vračila vložka. Gre predvsem za vprašanje, kdaj in ali sploh lahko družba proti tretjemu uveljavlja korporacijski vrnitveni zahtevek, kadar med njima korporacijsko razmerje sploh ni vzpostavljeno.

Če družba izvrši plačilo tretji osebi, ki bi za imetnika deležev pomenilo prepovedano plačilo, takšno plačilo pa se pod določenimi pogoji lahko pripiše slednjemu, se izplačilo obravnava kot (neposredno) izplačilo imetniku deležev. Temu se tako lahko na primer pripišejo izplačila družbe tretji osebi, ki pa dejansko prejme takšno izplačilo za račun imetnika deležev, ali izplačila, ki jih družba izvrši tretji osebi po njegovem naročilu, ali pa izplačila, katerih prejemnik je družinski član imetnika deležev ali druga $\mathrm{z}$ njim povezana oseba. Ker se $\mathrm{v}$ teh primerih za dejanskega prejemnika prepovedanega plačila šteje imetnik deležev sam, ne tretja oseba, je tudi imetnik deležev tisti, ki je družbi dolžan vrniti ta plačila (in ne tretja oseba). To velja tudi, če predmet prepovedanega vračila vložka dejansko ostane v rokah tretje osebe in ga ta ne izroči imetniku deležev. Družba torej v takšnih primerih zoper tretjega ne more uveljaviti zahtevka za vračilo prepovedanih plačil v smislu prvega odstavka 233. člena ZGD-1 (nima na razpolago korporacijskega vrnitvenega zahtevka), temveč ima tak zahtevek le v razmerju do imetnika deležev (ki je dejanski prejemnik plačila). Zoper tretjega pa ima družba lahko zahtevke na podlagi splošnih pravil civilnega prava, kot so na primer obligacijski (kondikcijski in odškodninski) in stvarnopravni zahtevki (reivindikacija).

Ne glede na to, da družba torej zoper tretje osebe načeloma ne more uveljavljati korporacijskega vrnitvenega zahtevka, se ji ta zoper tretje $\mathrm{v}$ določenih primerih vendarle priznava. Ta zahtevek je sankcija za kršitev načela prepovedi vračila vložka, predpostavke katerega pa se presojajo z vidika 227. člena ZGD-1. Obseg dejanskega stanja prepovedi vračila vložka tako določa tudi možnost uporabe sankcije, ki je posledica takega prepovedanega ravnanja. Če so tretje osebe lahko naslovniki

22 Zabel, B., Prelič, S. et al.: Družba z omejeno odgovornostjo; GV Založba, Ljubljana, 2009, stran 67. 
zakonske prepovedi vračila vložka v smislu 227. člena ZGD-1, lahko družba tudi zoper njih uveljavi korporacijski vrnitveni zahtevek.

\section{POSEBEJ O OHRANJANJU KAPITALA IN FINANČNI ASISTENCI V OBLIKI KREDITIRANJA, ZAGOTAVLJANJA POSOJIL IN ZAVAROVANJ}

Kako v pravila o ohranjanju kapitala, ki so bila podrobno razložena zgoraj, posežejo položaji, v katerih družba imetniku svojih deležev finančno asistira oziroma mu zagotavlja finančno asistenco na način, da mu bodisi neposredno daje posojila bodisi v breme svojega premoženja prevzema jamstva za obveznosti imetnika deležev?

Pod pojmom , finančna asistenca" razumemo:

- neposredno kreditiranje, torej tiste položaje, v katerih družba (neposredno) zagotavlja (daje) kredit oziroma posojilo imetniku svojih deležev (oziroma obrnjeno, ko imetnik deležev zagotavlja kredit oziroma posojilo družbi, imetnik deležev katere je), ter

- zagotavljanje zavarovanja za kredit oziroma posojilo, ki ga družba zagotovi (ustanovi) v korist tretje osebe, ki pa je (kot kreditodajalec) zagotovila (dala) kredit imetniku deležev družbe (oziroma obrnjeno, ko imetnik deležev zagotovi zavarovanje za kredit, ki ga je družbi zagotovila tretja oseba).

Pravno so torej možni različni položaji. Posojila med družbo in imetniki njenih deležev (torej družbeniki oziroma delničarji, v odvisnosti od pravnoorganizacijske oblike, v kateri je družba organizirana) lahko potekajo v obeh smereh: kot posojila družbe imetniku deležev (posojila up-stream) ali kot posojila imetnika deležev družbi (posojila down-stream). Zato ima lahko v razmerju do posameznega imetnika deležev družba položaj posojilodajalke ali položaj posojilojemalke. Možno je tudi, da družba zgolj zavaruje posojilo, ki ga imetniku njenih deležev odobri tretja oseba, oziroma da imetnik deležev zavaruje posojilo tretje osebe, ki ga je ta dala družbi.

Tovrstni posli (kreditni posli in posli zavarovanja) niso prepovedani sami po sebi, so pa omejeni s pravili korporacijskega prava o pravnih razmerjih med družbo in imetniki deležev (causa societatis), med katerimi so relevantna zgoraj razložena pravila o ohranjanju (vzdrževanju) kapitala. Kot je bilo razloženo, so ta pravila različno intenzivna, odvisno od pravnoorganizacijske oblike družbe, pomembna pa je tudi smer posojilnega toka. Pravila (delniškega prava) so strožja, kadar je posojilo dano delničarju, $v$ pravu družb $z$ omejeno odgovornostjo pa so pravila strožja, kadar družba dobi posojilo od družbenika. Te omejitve naj bi preprečile različna tveganja, zlasti za položaj upnikov družbe; kadar družba zagotavlja kredit posameznemu imetniku deležev, pa se ščiti tudi položaj drugih imetnikov deležev (te družbe).

Ker so primerljiva tveganja podana tudi pri zavarovanjih za posojila, ki jih dajo imetniku deležev tretje osebe (na primer banke), se tudi zanje uporabljajo smiselno enaka pravila kot za posojila. To velja še posebej za posojila družbe imetniku deležev.

Iz tega lahko izpeljemo sklep, da so kreditni posli oziroma posli zavarovanja dopustni, vendar le, kolikor ne povzročijo prepovedane posledice, ki se kaže v kršitvi pravil o ohranjanju kapitala. Zato je treba take posle vedno presojati glede na njihove učinke na vezano premoženje. 


\subsection{Posojila, ki jih družba daje imetniku deležev (posojila up-stream)}

ZGD-1 ne vsebuje izrecnih določb glede tovrstnih posojil. Za njihovo presojo so zato merodajna (vsa splošna) pravila o ohranjanju kapitala.

\subsubsection{Delniško pravo}

V delniškem pravu to prepoved uzakonja določba prvega odstavka 227. člena ZGD-1, po kateri družba vložkov ne sme vrniti in zanje ne sme priznati obresti. Konkretizacija tega načelnega pravila je v določbi drugega odstavka 227. člena ZGD1 , po kateri je delničarjem dopustno izplačati le delež v bilančnem dobičku, kar je bilo zgoraj podrobneje razloženo. ${ }^{23}$

Značilnost delniškega prava je, da pred izplačili delničarjem veže celotno premoženje družbe. Izplačila dovoljuje le $\mathrm{v}$ izrecno dopustnih položajih. ZGD1 transakcij med družbo in delničarji sicer ne prepoveduje, vendar le, kolikor ne zmanjšujejo vrednosti premoženja družbe; to je izraženo tudi v prepovedi prikritih vračil vložka (tretji odstavek 227. člena ZGD-1). Namen pravil je jasen: izplačilna prepoved dolžniškemu kapitalu zagotavlja prednost pred lastniškim.

Posojila up-stream (posojila družbe delničarju) sama po sebi (še) ne pomenijo kršenja pravil o ohranjanju kapitala: hkrati z zagotovitvijo posojila se namreč $\mathrm{v}$ korist družbe vzpostavi terjatev, katere predmet je obveznost vračila posojila, ki ga je delničarju družba dala. Vendar pa to še ne zagotavlja, da se vrednost premoženja družbe ne more zmanjšati: ni namreč nujno, da je vrednost terjatve družbe identična višini posojila, ki ga je dala. Merodajna je zato ex ante presoja vračljivosti posojila, pri čemer se uporabljajo splošna pravila vrednotenja terjatev za potrebe bilanciranja, upoštevaje načelo previdnosti. Ta presoja naj bi pokazala, da ni nobenega utemeljenega dvoma v sposobnost delničarja, da posojilo družbi vrne, oziroma da ni nobenega konkretnega tveganja, ${ }^{24}$ da prejemnik posojila ne bi mogel vrniti v celoti. Uveljavitev terjatve za vračilo posojila mora biti verjetna, ${ }^{25}$ to pa je tudi pogoj za pripoznanje terjatve $\mathrm{v}$ knjigovodskih izkazih in bilanci stanja $\mathrm{v}$ njeni celotni višini (SRS, točka 3.8). V nasprotnem se terjatev pripozna $\mathrm{v}$ ustrezno nižji vrednosti, za kolikor se posledično zmanjša vrednost premoženja zaradi posojila. Korporacijsko gledano, s tem posojilo dobi pomen prepovedanega vračila vložka. ${ }^{26}$

23 Glej navedbe v razdelku A.4.

24 Primeri, ki utemeljujejo konkretno tveganje, so denimo: neizpolnitev ali zamuda z izpolnitvijo drugih obveznosti, blokiran transakcijski račun, nespoštovanje bistvenih pogodbenih obveznosti, težave z likvidnostjo, izčrpanje kreditnih linij, dolžnikova pogajanja za odlog plačila, dolžnikova izguba, ki je „razjedla” velik del lastnega kapitala, ter previsoke obveznosti glede na dolžnikov lastni kapital. Podrobneje Cahn, A., Kredite an Gesellschafter - zugleich Anmerkung zur MPSEntscheidung des BGH; Institute for Law and Finance, Working paper series No. 98, 2/2009, stran 12. Podobno Wirsch, S., Die Vollwertigkeit des Rückgewähranspruch; Der Konzern št. 10/2009, stran 447.

25 Sodba nemškega vrhovnega sodišča v zadevi „MPS” (II ZR 102/07, z dne 1. decembra 2008, stran 9). Verjetnost, ki že meji na gotovost, se ne zahteva.

26 Uprava mora torej z vso potrebno skrbnostjo preveriti sposobnost delničarja, da vrne posojilo, in sklenitev pogodbe zavrniti, če je njegova sposobnost dvomljiva. Knjigovodska vrednost 
V posledici prepovedanega vračila vložka družba pridobi korporacijski vrnitveni zahtevek (233. člen ZGD-1). ${ }^{27}$ Odločilna je presoja ex ante, to je presoja, pri kateri se upošteva stanje ob nakazilu posojila, zato naknadno poslabšanje bonitete delničarja (posojilojemalca), ki ga ni bilo mogoče predvideti, in s tem povezana oslabitev terjatve $\mathrm{v}$ bilanci stanja ne povzročita naknadne prekvalifikacije posojila $\mathrm{v}$ prepovedano vračilo vložka, četudi družbi na koncu nastane izguba.

Z vidika pravil o ohranjanju kapitala se lahko kot sporna izkaže tudi neustrezna višina obresti. Če je dogovorjena višina obresti, ki naj jih delničar plača družbi, nižja od tržno primerljive, ima nastala razlika (tako imenovana obrestna škoda) pomen prepovedanega vračila vložka. ${ }^{28}$ Bilančno je obrestna škoda okoliščina, ki zmanjšuje vrednost terjatve za vračilo posojila (glavnice) in se v knjigovodskih izkazih in bilanci stanja pripozna v diskontirani višini. ${ }^{29}$

\subsubsection{Pravo družb z omejeno odgovornostjo}

V pravu družb z omejeno odgovornostjo so meje dopustnega kreditiranja širše, zato je obseg izplačilne prepovedi ožji. Po prvem odstavku 495. člena ZGD-1 družba premoženja, ki je potrebno za ohranitev osnovnega kapitala in vezanih rezerv, torej vezanega kapitala, družbenikom ne sme izplačati. Pri teh pojavnih oblikah družb pravna ureditev tako ne veže njihovega celotnega premoženja (kot velja $\mathrm{v}$ delniškem pravu), ampak le premoženje, ki ima v kapitalu kritje v njegovih vezanih kategorijah. ${ }^{30}$ Kot je bilo že navedeno, tudi pravo družb z omejeno odgovornostjo ob kršitvah izplačilne prepovedi priznava družbi korporacijski vrnitveni zahtevek (496. člen ZGD-1), posebnost pa je subsidiarna odgovornost drugih družbenikov. ${ }^{31} \mathrm{Z}$ actio pro socio ta zahtevek lahko uveljavlja vsak družbenik, in sicer na način in pod pogoji iz 503. člena ZGD-1.

Razloženo velja z vidika pravil o ohranjanju kapitala, ki so namenjena zaščiti upnikov. Vendar pa tudi pri družbah z omejeno odgovornostjo celotno premoženje družbe pripada družbi, ne njenim družbenikom. Enostranski posegi v korist (le) posameznega družbenika niso dovoljeni, čeprav so izvršeni v breme nevezanih kategorij lastnega kapitala (na primer prenesenega dobička ali drugih rezerv iz dobička). Zato je (pri družbah $z$ več družbeniki) potreben še sklep družbenikov, ki je lahko izpodbojen po splošnih pravilih o izpodbojnosti (522. člen v zvezi s 395. členom ZGD-1). Če od izplačil nimajo sorazmerno enake koristi vsi družbeniki, je sklep izpodbojen zaradi kršitve načela enakega obravnavanja družbenikov. To je torej relevantno za družbe z več družbeniki. Sklep, ki je v nasprotju s 495. členom ZGD-1,

terjatve se mora ujemati z nominalno vrednostjo. Če obstaja konkretno tveganje, je posojilo delničarju iz premoženja družbe dovoljeno le, če je ustrezno zavarovano.

27 O pravni naravi tega zahtevka podrobneje v razdelku A.5.3.

28 Glej tudi pri Kocbek, M., Veliki komentar Zakona o gospodarskih družbah; 1. knjiga, GV Založba, Ljubljana, 2014, stran 748, kjer kot primer prepovedanega vračila vložka izrecno šteje brezobrestno posojilo.

29 Wirsch, S., Die Vollwertigkeit des Rückgewähranspruch; Der Konzern št. 10/2009, stran 447.

30 Glej navedbe v razdelku A.2.

31 Podrobneje Podgorelec, P., Ohranjanje osnovnega kapitala pri d. o. o.; PiD, št. 8/2006, strani $1689-1691$. 
je ničen. ${ }^{32}$

$\mathrm{Z}$ vidika posojil up-stream to pomeni, da so taka posojila dovoljena, če izpolnjujejo merila dopustnosti, na način in pod pogoji, ki veljajo v delniškem pravu, ${ }^{33}$ tako glede glavnice kot glede obresti, ne glede na to, da je družba v času izplačila podbilancirana. Odločilna je namreč bilančna presoja. Drugače od delniškega prava dovoljuje pravo družb z omejeno odgovornostjo tudi bolj tvegana posojila ali posojila z obrestno mero, ki je nižja od tržno primerljive, a le, če družba izkazuje dovolj razpoložljivih kategorij lastnega kapitala, tako da ne more priti do posega $\mathrm{v}$ vezane kapitalske kategorije. Potreben je še sklep družbenikov. Če je posojilo dano le enemu od družbenikov, morajo za sklep glasovati vsi drugi družbeniki, sicer je sklep izpodbojen zaradi kršitve načela enakega obravnavanja.

\subsection{Zavarovanje družbe za posojilo, ki ga imetniku deležev daje tretja oseba}

Za razumevanje zavarovanj je nujna razlaga glede posojil, podana v prejšnjem razdelku. Neposredno zagotavljanje posojil namreč ni edina oblika finančne asistence, ki jo družba lahko opravi v korist imetnika njenih deležev. Namesto da imetniku deležev zagotovi posojilo, lahko posojila, ki jih dajo družbeniku tretje osebe, na primer banke, družba zavaruje. ${ }^{34}$

„Zavarovanje” pomeni zagotavljanje različnih oblik osebnih (na primer

32 Hueck/Fastrich, v: Baumbach/Hueck: GmbH-Gesetz; 18. izdaja, Beck, München, 2006, stran 413.

33 Glej navedbe v razdelku B.1.1.

34 Kakor tudi, če prevzame poroštvo za terjatev, ki jo ima imetnik deležev do tretje osebe; glej k temu tudi navedbe $\mathrm{v}$ opombi 5.

Primer iz slovenske sodne prakse: neka slovenska delniška družba se je kot porok zavezala svojemu delničarju - banki za njeno terjatev do prejemnika kredita, ki mu ga je banka zagotovila. Delniška družba je s tem, ko je prevzela poroštveno obveznost za terjatev banke (svojega delničarja) do prejemnika kredita, v korist banke, to je svojega delničarja, zagotovila zavarovanje za delničarjevo terjatev do tretje osebe. To ravnanje po dejanskih znakih ustreza dejanju, ki ustreza prepovedanemu vračilu vložka. Tudi prevzem poroštva družbe za terjatve njenega delničarja je torej dejanje prikritega vračila vložka; Bayer, W., Münchener Kommentar zum Aktiengesetz; Beck, München [2008], komentar $\S 57$, s tem v zvezi pravi: „,Wird nicht der Kredit eines Aktionärs gegenüber einem Dritten, sondern umgekehrt das von einem Drittem beim Aktionär aufgenommene Darlehen durch die AG besichert, so ist auch diese Sicherheitenbestellung nach § 57 unzulässig ...” Korist, ki jo je v tem primeru prejela banka, torej delničar poroka, je $\mathrm{v}$ tem, da za izpolnitev njene terjatve poleg glavnega dolžnika (kreditojemalca) kot porok jamči še delniška družba, to je družba, katere delničar je banka. Taka pogodbena (poroštvena) zaveza je položaj banke pomembno izboljšala, saj za izpolnitev terjatve v razmerju do kreditojemalca ne jamči le glavni dolžnik, temveč tudi delniška družba kot porok. Ta je s prevzemom poroštva $v$ korist svojega delničarja angažirala svoje premoženje in bi bila, če kreditojemalec svoje obveznosti v razmerju do banke - kreditodajalca ob zapadlosti ne bi izpolnil, zavezanka za izpolnitev kot porok. Ker pa je tak položaj zaradi zaščite vezanega kapitala kapitalske družbe prepovedan, je poroštvena pogodba (ker je sklenjena v nasprotju z zakonom) neveljavna (nična). To je ugotovitev slovenskih sodišč na vseh treh stopnjah (glej k temu sodbo Okrožnega sodišča v Mariboru, opr. št. I Pg 785/2014, sodbo Višjega sodišča v Mariboru, opr. št. I Pg 58/2017, ter sodbo Vrhovnega sodišča RS, opr. št. III Ips 79/2017). 
prevzem poroštva) ali stvarnih zavarovanj (na primer zastava premičnega premoženja ali pa ustanovitev hipoteke). Družba s tem podpre položaj, da imetnik deležev posojilo sploh lahko dobi, oziroma mu omogoči ugodnejše posojilne pogoje.

Tak asistenčni angažma družbe odpira enaka tveganja, kot jih odpirajo posojila, zato tudi za zavarovanja veljajo smiselno enaka pravila kot glede posojil. Da bi se zavarovanje lahko štelo za prikrito vračilo vložka, sta potrebna dva pogoja oziroma testa: ${ }^{35}$

- najprej se preizkuša, ali je nastop položaja, da bo zavarovanje uveljavljeno, sploh verjeten. Če ni, je operacija bilančno nevtralna, ker v tem primeru ni treba oblikovati rezervacij. Če je „unovčitev” zavarovanja verjetna, pa je treba nadalje preizkusiti,

- ali ima družba do imetnika deležev regresni zahtevek, za katerega ni nikakršnega konkretnega tveganja, da ga družba od imetnika deležev ne bi mogla uveljaviti.

Velja torej podobno kot pri terjatvi za vračilo posojila. Ker se zavarovanje unovči, ko imetnik deležev ni sposoben vrniti posojila, bo takšna nevarnost praviloma obstajala. Če obstaja konkretno tveganje, pa mora biti regresni zahtevek ustrezno zavarovan. Poslovodstvo družbe mora torej zagotoviti, da je morebitna verjetnost uveljavitve zavarovanja „nevtralizirana” s primerno zavarovanim regresnim zahtevkom; če ni, gre za primer prepovedanega vračila vložka po prvem odstavku 227. člena ZGD-1. Pri družbah z omejeno odgovornostjo je treba v zvezi z omejitvami, ki izhajajo iz pravil o ohranjanju kapitala, opraviti preizkus po 495. členu ZGD-1, torej ali je zagotovljena ohranitev neizplačljivih vezanih kapitalskih kategorij (osnovnega kapitala in vezanih rezerv).

Vprašanje je, ali (in kako) kršitev pravil o ohranjanju kapitala vpliva na veljavnost pravnega posla, sklenjenega med družbo in tretjo osebo (na primer banko), s katerim se ustanavlja zavarovanje (na primer poroštvene pogodbe ali pogodbe o ustanovitvi hipoteke). Nedvomno je položaj družbe najučinkoviteje zavarovan $\mathrm{s}$ sankcijo neveljavnosti posla; ničnostna sankcija najučinkoviteje sanira kršitev pravil o ohranjanju kapitala. V to smer gre tudi novejša slovenska sodna praksa. ${ }^{36}$

$\mathrm{Ob}$ tem bi se lahko postavil pomislek, da so zastopniška pooblastila poslovodstva družbe $\mathrm{v}$ razmerjih s tretjimi neomejena (32. člen ZGD-1). Skladno s tem pristopom poslovodstvo, ki sklene posel, s katerim družba prevzame poroštvo za obveznost imetnika deležev te družbe - torej posel, sklenjen v nasprotju s pravili

35 Kiefner, A., Aufsteigende Darlehen und Sicherheitenbegebung im Aktienrecht nach dem MoMiG; NZG, št. 21/2008, stran 803.

36 Glej naslednje sodne odločbe: sodba in sklep Okrožnega sodišča v Ljubljani, opr. št. V Pg 3131/2013, ter sodbi Višjega sodišča v Ljubljani, opr. št. VSL I Cpg 323/2013 in VSL I Cpg 1474/2012. V tej zvezi je zelo relevantna najnovejša odločba Vrhovnega sodišča RS, opr. št. III Ips 79/2017, ki v jedru poudarja: „V konkretnem primeru je šlo za pravni posel, sklenjen med delniško družbo in banko (delničarko), s katerim je bilo ustanovljeno zavarovanje v obliki Poroštvene pogodbe, kar predstavlja prikrito obliko prepovedanega vračila vložka in s tem prepovedano plačilo po 233. členu ZGD-1. Družba je namreč svoji delničarki (in to samo njej) zagotovila posebno korist, ki se šteje za vračilo vložka, saj je riziko neplačila kredita, ki ga je delničarka zagotovila tretji osebi (drugi družbi), prevzela delniška družba, in sicer v breme svojega premoženja. Zato se že zagotovitev takega zavarovanja šteje za prepovedano dejanje." 
o ohranjanju kapitala -, zlorabi svoja pooblastila, vendar to ne vpliva na veljavnost posla, sklenjenega s tretjo osebo (na primer banko), in sicer z utemeljitvijo, da je treba varovati tretjo osebo. ${ }^{37}$

Vendar pa to ne velja absolutno, temveč le, če je tretja oseba dobroverna. Če ve ali ji vsaj ne more ostati neznano, da poslovodstvo deluje v nasprotju z omejitvami (in je zloraba zastopniških pooblastil za tretjega očitna), zunanja neomejenost pooblastil - in s tem povezana zaščita tretje osebe - izgubi legitimnost. ${ }^{38}$

Nemško vrhovno sodišče (BGH) je ob obravnavi podobnih položajev poudarilo, da načela o zlorabi zastopniških pooblastil nastopijo, če pogodbeni partner družbe ve ali mu vsaj ne more ostati neznano, da je poslovodja prekoračil svoja zastopniška pooblastila. ${ }^{39}$ To naj bi še posebej veljalo takrat, kadar pravni posel za družbo (v konkretnem primeru sicer organizirano kot družba z omejeno odgovornostjo) pomeni prikrajšanje ${ }^{40} \mathrm{Za}$ zlorabo ni pomembno, ali poslovodja zavestno ravna v škodo družbe; zadošča že, da je poslovodja objektivno deloval v nasprotju s svojimi dolžnostmi, tretji pa je za to vedel oziroma mu ni moglo ostati neznano. Enako naj bi veljalo, če si poslovodja pred sklenitvijo pogodbe ni pridobil sklepa družbenikov, kadar je ta potreben, pri tem pa v takem primeru sploh več ni pomembno, ali je posel za družbo tudi škodljiv. ${ }^{41} \mathrm{Za}$ zlorabo zastopniških pooblastil velja tudi delovanje poslovodje $\mathrm{v}$ nasprotju z domnevno voljo družbenikov, kar je sopogodbeniku znano oziroma mu ne more ostati neznano. ${ }^{42}$

Pravna posledica zlorabe zastopniških pooblastil $\mathrm{v}$ teh primerih je, da je zastopnikova izjava volje brez pravnega učinka. Za takšen zaključek pa mora biti zloraba zastopniških pooblastil evidentna; huda malomarnost tretje osebe, zaradi katere za zlorabo zastopniških pooblastil ni vedela, ne zadostuje. ${ }^{43}$ Če je za tretjo osebo očitno, da družba krši izplačilno prepoved, potem je s prekoračitvijo zastopniških pooblastil seznanjena in se zoper družbo ne more sklicevati na zaupanje $\mathrm{v}$ neomejenost zastopniških pooblastil; družbe torej v razmerju do tretje osebe

37 Tako je Višje sodišče v Ljubljani, ko je presojalo veljavnost poroštvene pogodbe, s katero je delniška družba prevzela poroštvo za obveznosti svojega delničarja (druge družbe, ki je bila v njenem kapitalu udeležena z 91,5-odstnotnim deležem), ugotovilo ničnost poroštvene pogodbe, v jedru pa poudarilo (sklep VSL, opr. št. I Cpg 323/2013): ,, Ničnost zaveze o zavarovanju, ko gre za razmerje med obvladujočo in odvisno družbo, ima nujne posledice za prejemnika zavarovanja. Prejemnika zavarovanja je treba varovati. To pa ne velja takrat, kadar je kreditodajalec opustil skrbnost dobrega strokovnjaka in sprejel poroštvo, ki bi utegnilo predstavljati vračilo vložka po prvem odstavku 227. člena ZGD-1." Enako je izreklo isto sodišče v podobnem primeru (sodba in sklep VSL, opr. št. I Cpg 1474/2012): „Kreditodajalca kot prejemnika zavarovanja je treba načeloma varovati, razen, kadar ta ni $v$ dobri veri in bi lahko vedel, da se z zavarovanjem, $s$ katerim se zmanjšuje vrednost premoženja zastavitelja ...omogoča izvedba prikritega izplačila delničarju po 3. odstavku 227. člena ZGD-1."

38 Flume, $W$., Allgemeiner Teil des bürgerlichen Recht - das Rechtsgeschäft; 4. izdaja, Springer Verlag, Berlin Heidelberg, 1992, stran 789.

39 Sodba v zadevi opr. št. II ZR 337/05, z dne 10. aprila 2006.

40 Sodba v zadevi opr. št. II ZR 113/94, z dne 13. novembra 1995.

41 Sodba v zadevi opr. št. II ZR 211/87, z dne 14. marca 1988.

42 Sodba v zadevi opr. št. II ZR 56/82, z dne 5. decembra 1983.

43 Altmeppen, H., GmbHG Kommentar; 8. izdaja, Beck-Online, Beck, München, 2015, komentar $\S 30 \mathrm{GmbHG}, \mathrm{r}$. št. 165 ; v avstrijskem pravu naj bi zadostovala huda malomarnost. 
zagotovitev zavarovanja ne zavezuje. ${ }^{44}$ Od tretje osebe se ne zahteva, da bi morala o teh okoliščinah aktivno poizvedovati. ${ }^{45}$

Če je zaradi zlorabe zastopniških pooblastil posel brez pravnega učinka, je mogoče šteti, da pogodba med družbo in tretjo osebo sploh ni bila sklenjena, tako da pravni posel zastopanega (torej družbe, katere korporacijski zastopnik je zlorabil svoja zastopniška pooblastila) ne zavezuje, razen če tretja oseba ni vedela in tudi ni bilo očitno, da dano zavarovanje lahko pomeni kršitev izplačilne prepovedi. Ne zahteva pa se, da bi morala tretja oseba ob sklenitvi pravnega posla, s katerim družba krši izplačilno prepoved, sodelovati z družbo z namenom oškodovanja upnikov družbe; zadostuje, da to ve ali je to očitno. ${ }^{46}$ Slovenska sodna praksa take posle - pravne posle brez pravnega učinka - sicer obravnava kot primere ničnih pogodb. ${ }^{47}$

\section{OMEJITVE ZARADI KONCERNSKIH POVEZAV}

Upoštevati je treba tudi koncernske vidike. Vprašanje je, ali ta okoliščina zaradi posebnosti, ki veljajo v koncernih (predvsem dejstvo koncernskega privilegija), kakorkoli vpliva na zgoraj navedena pravila o ohranjanju kapitala.

$\mathrm{V}$ zvezi s koncerni je vsebinsko treba razlikovati dejanski (glej razdelek $1 \mathrm{v}$ nadaljevanju) in pogodbeni koncern (glej razdelek 2 v nadaljevanju).

$\mathrm{Z}$ vidika pravil o ohranjanju kapitala so $\mathrm{v}$ dejanskem koncernu položaji domala enaki, kot če koncernske povezave ne bi bilo.

\subsection{Dejanski koncern}

Čeprav po splošnih pravilih o ohranjanju kapitala zahtevek za vračilo prepovedanih plačil nastane takoj, ima v razmerjih dejanskega koncerna obvladujoča družba možnost odložene izravnave prikrajšanja zaradi ,koncernskega privilegija”. Prvi odstavek 545. člena ZGD-1 določa, da v koncernskih družbah, v katerih ni sklenjena pogodba o obvladovanju (tj. dejanski koncern), obvladujoča družba ne sme uporabiti svojega vpliva, da bi odvisno družbo pripravila do tega, da bi zase opravila škodljiv pravni posel ali da bi kaj storila ali opustila v svojo škodo, razen če obvladujoča družba prikrajšanje nadomesti. Prikrajšanje pa se lahko nadomesti tudi tako, da se najpozneje do konca poslovnega leta, v katerem je bila odvisna družba prikrajšana, ustanovi izravnalni zahtevek v korist odvisne družbe (drugi odstavek 545. člena ZGD-1).

44 Bayer, W., Münchener Kommentar zum Aktiengesetz; Beck, München, 2016, komentar $§ 57$ AktG, r. št. 239.

45 Altmeppen, H., GmbHG Kommentar; 8. izdaja, Beck-Online, Beck, München, 2015, komentar $\S 30 \mathrm{GmbHG}, \mathrm{r}$. št. 166.

46 Bayer, W., Münchener Kommentar zum Aktiengesetz; Beck, München, 2016, komentar $§ 57$ AktG, r. št. 237.

47 Odločba VSRS, opr. št. II Ips 13/1999, z dne 23. septembra 1999. Tudi novejši judikati gredo v to smer (sodba VSRS, opr. št. II Ips 229/2014, z dne 2. julija 2015): ,,V skladu z ustaljeno sodno prakso namreč pogodba, ki jo je »sklenila " poslovno nesposobna oseba, sploh ni nastala in je nična." 
Za posojila up-stream je uporabnost koncernskega privilegija ozka, upoštevajoč specifičnosti prikrajšanj, ki lahko nastanejo zaradi teh pravnih poslov. Ob konkretiziranem tveganju, da obvladujoča družba ne bo sposobna vrniti posojila, sta praktično edina učinkovita načina izravnave prikrajšanja ustrezno zavarovanje ali takojšnje vračilo posojila, če je bilo to že izplačano. To ne more biti ustanovitev izravnalnega zahtevka, saj ta $\mathrm{v}$ teh okoliščinah nima nobenega pravega smisla. ${ }^{48}$

Podobno velja za zavarovanja up-stream. Prikrajšanje v obliki verjetnosti uveljavitve zavarovanja je mogoče nadomestiti le z ustreznim zavarovanjem regresnega zahtevka. Teorija pa zastopa še stališče, da zavarovanje up-stream pomeni prikrajšanje per se, saj se odvisni družbi zmanjšujejo možnosti zavarovanja lastnih obveznosti; zlasti to velja pri stvarnih zavarovanjih. Izjema je, če med koncernskimi družbami obstaja sistem medsebojnih zavarovanj obveznosti do tretjih oseb, s čimer se povečuje kreditna sposobnost odvisne družbe. Nesporna so zavarovanja za posojila, ki jih najame obvladujoča družba, vendar finančna sredstva preusmeri na odvisno družbo, kar pa v konkretnem primeru, po posredovanih podatkih, naj ne bi bilo uresničeno.

Manevrski prostor za izravnalni zahtevek po drugem odstavku 545. člena ZGD1 obstaja le za prikrajšanja zaradi obrestne mere, ki je nižja od tržno primerljive. Obrestno škodo je torej mogoče (začasno) dopustiti in jo kasneje nadomestiti na enega od siceršnjih načinov izravnave prikrajšanja. Enako velja za provizijo za zavarovanja terjatev tretjih oseb (na primer bank) do drugih koncernskih družb.

Kljub „pritiskom” obvladujoče družbe mora torej poslovodstvo odvisne družbe zavrniti posojilo, če je povezano s prevelikim kreditnim tveganjem, sicer krši svoje dolžnosti (prvi odstavek 263. člena ZGD-1) in tako odgovarja za škodo, ki nastane odvisni družbi, solidarno z obvladujočo družbo in njenimi zastopniki (547. člen ZGD-1). Preveriti mora boniteto obvladujoče družbe in sme posojilo odobriti le, če ni nobenega utemeljenega dvoma o sposobnosti za njegovo celotno vračilo. Paziti mora tudi, da posojilo ne ogroža likvidnosti odvisne družbe.

Dolžnosti poslovodstva odvisne družbe s tem še niso izčrpane. Tudi po tem, ko je posojilo že nakazano, mora sproti preverjati, ali se je kreditno tveganje spremenilo, in se na morebitno poslabšanje posojilojemalčeve bonitete odzvati z zahtevo za ustrezno zavarovanje posojila oziroma $\mathrm{z}$ odstopom od pogodbe in z zahtevo za takojšnje vračilo posojila. ${ }^{49} \mathrm{~V}$ zvezi s tem je $\mathrm{v}$ posojilno pogodbo treba zapisati ustrezen dogovor o informacijskih upravičenjih in upravičenjih do zavarovanja oziroma do odstopa od pogodbe. V pogodbi naj bi bile čim natančneje definirane okoliščine in dogodki, od nastanka katerih je odvisna pravica do zavarovanja oziroma odstopa od pogodbe (na primer poslabšanja določenih bilančnih kazalnikov, izgube, ki presegajo določen znesek, zamujanje $\mathrm{z}$ izpolnitvami $\mathrm{v}$ razmerjih $\mathrm{z}$ drugimi kreditorji in podobno). Te pogodbene pravice pa odvisni družbi ne pomagajo prav veliko, če obstajajo razlogi za izpodbijanje pravnih dejanj $\mathrm{v}$ stečajnem postopku.

48 Habersack. M., v: Emmerich/Habersack: Aktien- und GmbH-Konzernrecht; 6. izdaja, Beck, München, 2010, stran 583.

49 Glej sodbo, citirano v opombi 26, stran 10. 


\subsection{Pogodbeni koncern}

$\mathrm{V}$ pogodbenem koncernu, katerega podlaga je pogodba o obvladovanju, ima obvladujoča družba pravico odvisni družbi dajati navodila za vodenje poslov. Lahko daje tudi navodila, ki so za odvisno družbo škodljiva (prvi odstavek 541. člena ZGD-1). Vendar pa mora obvladujoča družba prevzeti jamstvo za eksistenco odvisne družbe: zavezana je odvisni družbi poravnati vsako med trajanjem pogodbe nastalo letno izgubo (prvi odstavek 542. člena ZGD-1). Položaj zunanjih imetnikov deležev varuje pravica do primernega nadomestila oziroma odpravnine (552. in 553. člen ZGD-1). Preneseno na polje posojil in zavarovanj to pomeni, da lahko odvisna družba po navodilu obvladujoče družbe daje tudi škodljiva posojila up-stream, to je taka posojila, ki ne ustrezajo merilom, utemeljenim na pravilih o ohranjanju kapitala (preveč tvegana in neustrezno obrestovana posojila), obvladujoči družbi ali drugim koncernskim družbam. ${ }^{50}$ Omejena je s pogojem, da bo obvladujoča družba sposobna poravnati izgubo, ${ }^{51}$ sicer mora poslovodstvo odvisne družbe tudi $\mathrm{v}$ pogodbenem koncernu zavrniti izplačilo posojila.

$\mathrm{V}$ pogodbenem koncernu se torej dolžnost preizkusa, ali bo prejemnik sposoben vrniti posojilo, izraža kot preizkus verjetnosti poravnave letne izgube, če jo je mogoče pričakovati. Če je ta verjetnost potrjena, so posojila drugim koncernskim družbam dovoljena, čeprav je njihova vračljivost zaradi slabe bonitete prejemnika posojila dvomljiva. Enako velja, če je med obvladujočo in odvisno družbo sklenjena pogodba o prenosu dobička iz drugega odstavka 533. člena ZGD-1.

\section{POVZETEK NORMATIVNIH IZHODIŠC̆}

$\mathrm{Na}$ podlagi vseh razloženih spoznanj teorije korporacijskega prava, ki so bila razložena $\mathrm{v}$ prejšnjih razdelkih, lahko ugotovimo, da so posojila med družbo in imetniki njenih deležev načeloma dopustna (in jih torej korporacijsko pravo ne prepoveduje a priori). Enako velja za zavarovanja (osebna ali stvarna), s katerimi družba zavaruje dolg imetnika deležev do tretje osebe..$^{52}$

Vendar pa lahko hkrati tudi ugotovimo, da $\mathrm{v}$ nekaterih primerih taki posli utegnejo povzročiti uresničitev prepovedanega korporacijskega položaja, to je položaja prepovedanega vračila vložka. Če tak položaj nastopi, povzroči nastanek korporacijskega vrnitvenega zahtevka, lahko pa tudi ničnost pravnega posla, vključno z ničnostjo pravnega posla zagotovitve zavarovanja.

Slovensko korporacijsko pravo torej $\mathrm{z}$ določbami 227. ( $\mathrm{v}$ delniškem pravu) oziroma 495. člena ZGD-1 (v pravu družb z omejeno odgovornostjo)

50 Sklenitev pogodbe o obvladovanju ali prenosu dobička suspendira splošna pravila o ohranjanju kapitala. Četrti odstavek 533. člena ZGD-1 določa, da se plačila družbe na podlagi pogodbe o obvladovanju ali pogodbe o prenosu dobička ne štejejo za kršitev 227. in 230. člena ZGD-1. To pravilo se smiselno uporablja tudi za družbe z omejeno odgovornostjo.

51 Altmeppen, H., „Upstream-loans”, Cash Pooling und Kapitalerhaltung nach neuem Recht; Zeitschrift für Wirtschaftsrecht, št. 2/2009, stran 55.

52 Ali pa tudi, kot v primeru, opisanem v opombi 35, če prevzame jamstvo za terjatev imetnika deležev do tretje osebe. 
generalnopreventivno prepoveduje nastop položaja, v katerem bi prišlo do kršitve pravil o ohranjanju kapitala s prepovedanimi vračili vložka. Jasno pri tem je, da tak položaj ne more nastopiti sam od sebe, ampak ga utegnejo povzročiti različna (pravnoposlovna) ravnanja, ki jih družba opravi v razmerju do imetnikov svojih deležev (oziroma v njihovo korist). Med taka ravnanja spada, kot je bilo razloženo, tudi sklepanje kreditnih poslov v korist imetnikov deležev, predvsem pa tudi poslov, $\mathrm{s}$ katerimi družba $\mathrm{v}$ zavarovanje kredita, ki ga imetniku deležev podeli tretja oseba, prevzame svoje (osebno ali stvarno) jamstvo. Hkrati s tem je treba upoštevati, da sklepanje takih poslov družbi ni prepovedano samo po sebi, temveč le, kolikor ti posli privedejo do posledice, ki je korporacijsko prepovedana (učinek vračila vložka). Zato taki posli niso neveljavni sami po sebi, ampak le, če povzročijo nastanek prepovedane posledice, to je, da učinkujejo kot vračilo vložka: pravni posel zavarovanja, ki ga družba prevzame do banke (bodisi kot porok bodisi kot zastavitelj za kredit, ki ga je banka dala družbeniku), je torej lahko ničen, če gre pri tem za prepovedano vračilo vložka in če pri tem ni podana dobra vera banke. V to smer se nagiba slovenska sodna praksa. ${ }^{53}$

Pri zavarovanjih velja, da sta potrebna dva testa presoje, ki pokažeta, ali gre za nezakonito transakcijo. Najprej je treba pretehtati verjetnost uveljavitve zavarovanja, torej presoditi verjetnost, da bo kreditodajalec (banka) dejansko unovčil predmet zastave ali pa terjal izpolnitev od družbe kot poroka. Tak položaj bo v praksi skoraj zanesljivo uresničen tedaj, ko imetnik deležev, ki najema posojilo, sam niti ne more zagotoviti zavarovanja in nujno potrebuje zavarovanje s strani tretje osebe (bodisi hčerinske družbe ali družbe, v kateri je kapitalsko udeležen). Gre torej za položaje, ko je družba kreditojemalka $v$ času najemanja kredita va slabem finančnem stanju (denimo plačilno nesposobna) in posojila brez finančne asistence v obliki zavarovanja tretjega ne more dobiti. To je pomemben kazalnik finančnega položaja, na katerega bi kreditodajalci morali biti še posebej pozorni, saj nakazuje na potencialno korporacijsko spornost zavarovanja.

Drugi test pa mora pokazati, da družba zaradi unovčitve zavarovanja ne bo mogla realizirati regresnega zahtevka zoper imetnika deležev, čigar obveznost je zavarovala, ker je ta neplačevit. Ker imetnik deležev ne more vrniti kredita, tudi ne more tudi poplačati regresne obveznosti do družbe, te pa pred tem tudi ni zavaroval. Če torej regresni zahtevek družbe zoper družbenika ni ustrezno zavarovan in obstaja konkretno tveganje glede obeh testov, potem je v korporacijskem smislu učinek posla, s katerim je družba prevzela zavarovanje, tak, da gre za prepovedano vračilo vložka po 227. oziroma 495. členu ZGD-1.

Pri tem je treba upoštevati, da ni ničen kreditni pravni posel, torej kavzalni pravni posel, na temelju katerega je banka zagotovila kredit imetniku deležev, temveč se morebitna ničnost nanaša na pravni posel, katerega predmet je zavarovanje, torej pogodba o poroštvu ali zastavna pogodba. $\mathrm{Z}$ zagotovitvijo zavarovanja je namreč podan povod za prepovedano vračilo vložka, ki ima pojavno obliko »zagotovitve zavarovanja

Banka - kreditodajalka pri transakciji z družbo sodeluje pri nezakonitem

53 Glej sodne odločbe, citirane v opombah 37 in 38. 
prepovedanem vračilu vložka. Zato je pravni posel, ki ga sama sklene z družbo to pa je sklenitev pogodbe o poroštvu ali zastavne pogodbe -, ničen, če ob tem ni podana njena dobrovernost, torej da je za potencialno nezakonitost $\mathrm{v}$ delovanju druge pogodbene stranke vedela. Banka je torej tista, ki naj bi bila v slabi veri glede vseh elementov in predpostavk, da ima posel ustanovitve zavarovanja, ki ga sklepa z družbo, učinek (družbi) prepovedanega vračila vložkov. Zato mora poznati razmerje med družbo in imetnikom deležev, vključno z bonitetnim stanjem slednjega kot posojilojemalca, ki je táko, da mu onemogoča, da bi najeti kredit mogel zavarovati sam (in je zato kot dajalec zavarovanja nastopila družba, imetnik deležev katere je).

Pri tem naj poudarimo, da je problem ugotavljanja dobro- oziroma slabovernosti banke vprašanje ugotavljanja standarda. Ta se ugotavlja $\mathrm{v}$ vsakem konkretnem primeru posebej, upoštevaje vsakokratni okvir dejanskih okoliščin, kot so podane. Dokazovanje dobrovernosti banke - torej da ni poznala korporacijskega razmerja med družbo in imetnikom deležev (posojilojemalcem) ter da ni poznala tveganj pri prevzetih posojilih ali danih zavarovanjih -, je, predvsem ob upoštevanju standardov bančnega poslovanja oziroma zahtev po ustrezni profesionalni skrbnosti bank pri odobravanju posojil, bržkone težavno. Vsekakor je to problem banke - kreditodajalke.

Tudi če je zavarovanje ustrezno, tveganje unovčitve zavarovanja pa sploh ni podano, mora biti zavarovanje, ki ga družba zagotavlja za obveznost imetnika njenih deležev, še ustrezno odplačno z njegove strani. Če je neodplačno, je v tem delu izvršeno prepovedano vračilo vložka.

Naj še enkrat opozorimo, da je pri delniških družbah vezano celotno premoženje družbe, ne le vezani kapital, saj so izplačila dopustna le iz bilančnega dobička. Zato je posel prepovedan tudi, če bi zavarovanje bremenilo proste (nevezane) sestavine kapitala, torej proste rezerve iz dobička. Tudi v takem primeru bi - v primeru delniške družbe kot dajalca zavarovanja - šlo za prepovedano vračilo vložka in s tem za nedovoljeno transakcijo. V pravu družb $\mathrm{z}$ omejeno odgovornostjo pa se prepoved nanaša na osnovni kapital in vezane rezerve, ki jih tvorijo kapitalske rezerve in zakonske rezerve (kot prva sestavina rezerv iz dobička). Transakcije torej ne smejo biti opravljene $\mathrm{v}$ breme vezanega kapitala. ${ }^{54}$

\section{LITERATURA}

Knjige in prispevki:

1. Altmeppen, Holger, „Upstream-loans”, Cash Pooling und Kapitalerhaltung nach neuem Recht; Zeitschrift für Wirtschaftsrecht, br. 2., 2009.

2. Altmeppen, Holger, GmbHG Kommentar, 8. izdaja, Beck-Online, Beck, München, 2015.

3. Artmann, Eveline, Aktiengesetz Kommentar, Manz, Wien, 2004.

4. Bayer, Walter, Münchener Kommentar zum Aktiengesetz, Beck, München, 2008.

5. Bayer, Walter, Münchener Kommentar zum Aktiengesetz, Beck, München, 2016.

54 Posledično to pomeni, da so $\mathrm{v}$ pravu družb $\mathrm{z}$ omejeno odgovornostjo dopustna zavarovanja (in posojila), ki so dana $\mathrm{v}$ breme nevezanega kapitala, torej $\mathrm{v}$ breme razpoložljivih prostih kapitalskih kategorij. V tem primeru se šteje, da interes upnikov ni prizadet, lahko pa bi bil prizadet interes družbenikov. Zato so prepovedana enostranska razpolaganja družbe v obliki dajanja posojil ali zagotavljanja zavarovanj, če bi ti posli pomenili korist zgolj za posameznega družbenika. Zato mora odločitev potrditi še skupščina. 
6. Cahn, Andreas, Kredite an Gesellschafter - zugleich Anmerkung zur MPS-Entscheidung des BGH, Institute for Law and Finance, Working paper series No. 98, 2/2009.

7. Flume, Werner, Allgemeiner Teil des bürgerlichen Recht - das Rechtsgeschäft; 4. izdaja, Springer Verlag, Berlin Heidelberg, 1992.

8. Habersack, Mathias, v: Emmerich/Habersack, Aktien- und GmbH-Konzernrecht, 6. izdaja, Beck, München, 2010.

9. Henze, Harting, Aktiengesetz Großkommentar, deGruyter, 2001.

10. Henze, Harting, Aktiengesetz Großkommentar, deGruyter, Berlin, 2000.

11. Hueck/Fastrich, v: Baumbach/Hueck, GmbH-Gesetz, 18. izdaja, Beck, München, 2006.

12. Hüffer, Uwe, Aktiengesetz Kommentar, Beck, München, 2004.

13. Kiefner, Alexander, Aufsteigende Darlehen und Sicherheitenbegebung im Aktienrecht nach dem MoMiG; NZG, br. 21., 2008.

14. Kobal, Aleš, Pravna narava zahtevka delniške družbe za vračilo prepovedanega vračila vložka, Podjetje in delo, br. 2., 2008.

15. Kocbek, Marjan, Prelič, Saša, Zakon o gospodarskih družbah (ZGD-1) z novelama ZGD1A in ZGD-1B, GV Založba, Ljubljana, 2008.

16. Kocbek, Marjan, Veliki komentar Zakona o gospodarskih družbah, 1. knjiga, GV Založba, Ljubljana, 2014.

17. Kocbek, Marjan, Veliki komentar ZGD-1, II. knjiga, GV Založba, Ljubljana, 2006.

18. Kocbek, Marjan, Veliki komentar ZGD-1, II. knjiga, GV Založba, Ljubljana, 2007.

19. Kocbek, Marjan, Zakon o gospodarskih družbah s komentarjem, I. knjiga, GV Založba, Ljubljana, 2012.

20. Lutter, Marcus, Kölner Kommentar zum Aktiengesetz, Heymanns, Köln-Berlin-BonnMünchen, 1988. Bayer, Münchener Kommentar zum Aktiengesetz, Beck/Vahlen, München, 2003.

21. Podgorelec, Peter, Ohranjanje osnovnega kapitala pri d. o. o., Podjetje in delo, br. 8, 2006.

22. Saurer, Ulrich, Kommentar zum Aktiengesetz, Linde, Wien, 2003.

23. Schmidt, Karsten, Gesellschaftsrecht, Heymanns, 1997.

24. Wirsch, Stefan, Die Vollwertigkeit des Rückgewähranspruch, Der Konzern, br. 10, 2009.

25. Zabel, Bojan, v: Prelič et al., Družba z omejeno odgovornostjo, GV Založba, Ljubljana, 2009.

Sodna praksa:

1. Odločba Vrhovnega sodišča RS, opr. št. III Ips 79/2017.

2. Odločba Vrhovnega sodišča RS, opr. št. II Ips 13/1999, z dne 23. septembra 1999.

3. Sklep Višjega sodišča v Ljubljani, opr. št. I Cpg 323/2013.

4. Sodba in sklep Okrožnega sodišča v Ljubljani, opr. št. V Pg 3131/2013.

5. Sodba in sklep Višjega sodišča v Ljubljani, opr. št. I Cpg 323/2013 ter VSL I Cpg $1474 / 2012$.

6. Sodba in sklep Višjega sodišča v Ljubljani, opr. št. I Cpg 1474/2012.

7. Sodba nemškega vrhovnega sodišča v zadevi »MPS« (II ZR 102/07, z dne 1. decembra 2008, stran 9.

8. Sodba Okrožnega sodišča v Mariboru, opr. št. I Pg 785/2014.

9. Sodba v zadevi opr. št. II ZR 113/94, z dne 13. novembra 1995.

10. Sodba v zadevi opr. št. II ZR 211/87, z dne 14. marca 1988.

11. Sodba v zadevi opr. št. II ZR 337/05, z dne 10. aprila 2006.

12. Sodba v zadevi opr. št. II ZR 56/82, z dne 5. decembra 1983.

13. Sodba Višjega sodišča v Mariboru, opr. št. I Pg 58/2017.

14. Sodba Vrhovnega sodišča RS, opr. št. III Ips 79/2017.

15. Sodba Vrhovnega sodišča RS, opr. št. II Ips 229/2014, z dne 2. julija 2015.

16. Sodba Vrhovnega sodišča RS, opr. št. III Ips 109/2011.

17. Sodba Vrhovnega sodišča RS, opr. št. III Ips 79/2017. 


\section{Saša Prelič* \\ Marijan Kocbek**}

Sažetak

\section{DOPUSTIVOST FINANCIJSKE ASISTENCIJE OVISNOG DRUŠTVA ZA OBVEZE VLADAJUĆEG DRUŠTVA}

Autori u radu obrađuju dopustivost različitih oblika financijske asistencije između trgovačkog društva i njegovih članova, odnosno dioničara. Prikazano je pravno uređenje u slovenskom pravu društava te aktualna slovenska i njemačka sudska praksa. Temeljni je zaključak da zajmove društva članovima (up-stream zajmovi) treba prosuđivati sukladno prisilnim općim pravilima o očuvanju kapitala društva, a isto vrijedi i za davanje osiguranja za zajmove trećih osoba, primjerice banaka. Financijska asistencija će biti dopuštena samo ako ne predstavlja zabranjeni povrat uloga u društvo. Također se obrađuju posebnosti koje vrijede u slučajevima koncernsko povezanih društava.

Ključne riječi: dioničko društvo; društvo s ograničenom odgovornošću; zajam; osiguranje; zabranjena financijska asistencija.

\section{Summary}

\section{PERMISSIBILITY OF FINANCIAL ASSISTANCE OF SUBSIDIARY FOR OBLIGATIONS OF PARENT COMPANY}

This paper deals with the financial assistance between a company and its shareholders. In particular, it sheds light on the current regulations in Slovenian company law, while analysing the relevant Slovenian and German jurisprudence. The authors emphasize that upstream loans and upstream insurances for loans given by third party (e.g. banks), have to be monitored by virtue of strict capital maintenance rules. Financial assistance is allowed if not in contradiction with capital preservation. The authors also underline the regulation pertaining to groups of companies.

Keywords: public limited company; private limited company; loan; insurance; prohibited financial assistance.

\footnotetext{
* Dr. sc. Saša Prelič, redoviti profesor, Pravni fakultet, Sveučilište u Mariboru, Slovenija; sasa. prelic@um.si.

** Dr. sc. Marijan Kocbek, redoviti profesor, Pravni fakultet, Sveučilište u Mariboru, Slovenija; marijan.kocbek@um.si.
} 
Zussamenfassung

\section{DIE ZULÄSSIGKEIT DER FINANZIELLEN UNTERSTÜTZUNG AN DIE TOCHTERGESELLSCHAFT ANGESICHTS DER VERPFLICHTUNGEN DER MUTTERGESELLSCHAFT}

In diesem Beitrag wird die Zulässigkeit unterschiedlicher Formen finanzieller Unterstützung bearbeitet, welche die Handelsgesellschaft ihren Mitgliedern, beziehungsweise Aktionären, gewährt. Die Rechtsregelung im slowenischen Gesellschaftsrecht sowie auch die aktuelle slowenische und deutsche Rechtsprechung werden im Beitrag dargestellt. Es lässt sich schließen, dass man die UpstreamDarlehen gemäß den aufgezwungenen allgemeinen Regeln über Kapitalaufbewahrung bewerten muss, was auch für Drittsicherungsgeber, beispielsweise Banken, gilt. Die finanzielle Unterstützung wird nur dann zugelassen, wenn es sich nicht um die verbotene Rückgabe der Einlage an die Gesellschaft handelt. Es werden auch die Besonderheiten bezüglich Konzerne bearbeitet.

Schlüsselwörter: Aktiengesellschaft; Gesellschaft mit beschränkter Haftung; Darlehen; Sicherung; verbotene finanzielle Unterstützung.

Riassunto

\section{L'AMMISSIBILITÀ DELL'ASSISTENZA FINANZIARIA DELLA SOCIETÀ DIPENDENTE PER LE OBBLIGAZIONI DELLA SOCIETÀ DOMINANTE}

Gli autori nel lavoro analizzano l'ammissibilità delle diverse forme di assistenza finanziaria tra la società commerciale ed i suoi soci, ovvero azionisti. Viene illustrata la disciplina giuridica nel diritto societario sloveno, come anche l'attuale giurisprudenza slovena e tedesca. La conclusione fondamentale cui si perviene è che i finanziamenti della società ai soci (up-stream finanziamenti) vanno valutati nel rispetto alle regole generali cogenti relative alla protezione del capitale della società; ciò vale anche per la prestazione di garanzia per i finanziamenti a soggetti terzi, quali le banche. L'assistenza finanziaria sarà ammessa soltanto allorquando non costituisca una restituzione vietata dell'investimento nella società. Si trattano altresì le peculiarità che valgono nei casi di società collegate in un gruppo.

Parole chiave: società per azioni; società a responsabilità limitata; finanziamento; garanzia; assistenza finanziaria vietata. 
